Working Paper in Economics No. 764

\title{
The Impact of Upper Secondary School Flexibility on Sorting and Educational Outcomes
}

\section{Andrea Berggren and Louise Jeppsson}

Department of Economics, May 2019 


\title{
The Impact of Upper Secondary School Flexibility on Sorting and Educational Outcomes
}

\author{
Andrea Berggren ${ }^{\mathrm{a}}$ and Louise Jeppsson ${ }^{\mathrm{b}}$ \\ ${ }^{a}$ University of Gothenburg $\dagger$ \\ ${ }^{\mathrm{b}}$ University of Gothenburg $\dagger$
}

May 13, 2019

\begin{abstract}
This paper estimates the causal impact of an upper secondary curriculum reform in Sweden that increased students' course-taking flexibility in year 2000. In the most popular upper secondary program, it led to a significant decrease in mandatory mathematics requirements. Using administrative Swedish data, we estimate the causal impact of the reform on tertiary education outcomes and expected earnings using a differences-in-discontinuity identification strategy. The method compares students born immediately before and after the cutoff date. The inclusion of students born in neighboring non-reform cutoff years enables us to disentangle the school starting age effect from the unconfounded effect of the reform. We find no negative effects of the reduced mathematics requirements. Rather, we find a positive effect of the reform on students' probability of enrolling in, and earning a degree from, tertiary education. Our heterogeneity analysis suggests that relatively disadvantaged students were not negatively affected by the reform.
\end{abstract}

Keywords: Educational Economics; Upper secondary school curriculum; Course selection; Tertiary education; Returns to education; Reform evaluation; Human Capital JEL Classification: I21, I23, I26, I28

$\dagger$ Department of Economics, University of Gothenburg. Address: Vasagatan 1, 40530 Gothenburg, Sweden. Contact: Andrea Berggren: andrea.berggren@economics.gu.se, Corresponding author: Louise Jeppsson: louise.jeppsson@economics.gu.se

Acknowledgements: The authors are grateful for comments from Mikael Lindahl, Fredrik Carlsson, Peter Fredriksson, Gustav Kjellsson, Peter Martinsson, Magne Mogstad, Michael Mueller-Smith, Mårten Palme, Måns Söderbom, Debbie Axlid and from participants at seminars at the Department of Economics at University of Gothenburg and Växjö University. 


\section{Introduction}

A well-educated labor force in science, technology, engineering, and math (STEM) offers a competitive edge in the global economy. Skills in mathematics and science have been shown to be positively associated with economic growth (Hanushek and Kimko, 2000). Policy makers in industrialized countries have shown great interest in improving the accumulation of such skills through curriculum reforms and better preparation of young individuals for tertiary education $\sqrt[1]{1}$ Herein lies a potential trade-off for the policy maker. What should the school curriculum consist of, and in what amounts? When determining the school curriculum, policy makers need to make choices regarding the overall time devoted to different subjects and what subjects should be compulsory. These choices reflect priorities and preferences concerning what knowledge and skills should be required, and there is substantial heterogeneity in curriculum priorities across countries ( $\mathrm{OECD}, 2018)$. More advanced education leads to a higher human capital stock, but enforcing a too strict curriculum might also lead less able students to shy away from further investments in human capital. Critics of a strict curriculum that offers little flexibility argue that restricting students' choices is undemocratic since mandating a fixed curriculum for all students deprives them of the opportunity to take courses they are interested in and that are in line with their personal aspirations (Noddings, 2011). On the other hand, under a flexible curriculum, students with potentially high returns to more advanced courses may opt out of those courses and hence reduce their tertiary education prospects.

Course selection is a central feature of any upper secondary curriculum. This paper examines whether students' tertiary education outcomes and annual expected earnings improve with a more flexible course selection system, i.e., a system that gives students greater freedom to choose courses based on individual preferences. First, we examine how increased course selection flexibility alters students' course-taking behavior. Second, we ask if increased course selection flexibility has a causal impact on tertiary education outcomes and annual expected earnings. Finally, we examine the distributional effects along the dimensions of parents' socioeconomic status (SES) and students' final grade point average (GPA) from lower secondary school. To answer the research questions, we make use of a curriculum reform implemented

\footnotetext{
${ }^{1}$ See for example Görlitz and Gravert (2018) investigating reform changes in Germany; Ning (2014), Sosa (2016) and Goodman (2017) investigating reform changes in the U.S. and Joensen and Nielsen (2016) investigating curriculum reform changes in Denmark.
} 
in all Swedish upper secondary schools in year 2000.

We use detailed Swedish administrative data, containing the entire population of upper secondary school students, to estimate the causal average impact of course selection flexibility in a regression discontinuity $(\mathrm{RD})$ framework. The identification strategy exploits that a student's birth date decided whether he/she started upper secondary school when the curriculum was less flexible or after more flexibility was introduced in autumn 2000. We compare students born in a 3 months window around the cutoff date, i.e., October 1983-March 1984. However, in the RD estimations we cannot disentangle the school starting age effect on outcomes from the true effect of the curriculum reform 2 To tease out the unconfounded effect on outcomes we follow Carneiro et al. (2015) and Bertrand et al. (2019) and employ a difference-in-discontinuity design where we augment the RD regression with students born in October-March in neighboring non-reform cutoff years $3^{3}$

We focus on the most popular upper secondary school program in Sweden, the Social Science program, which the reform had a particularly noticeable effect on 4 Prior to the reform, the Social Science program had one of the most rigid course curricula, offering limited flexibility for students to choose courses. With the reform, the share of elective courses increased from 9 to $18-24$ percent.5 Furthermore, 25 percent of the previously mandatory mathematics coursework was moved to a list of elective courses (GyVux 1994/97:16; GY2000:16). No such change occurred in any other Swedish upper secondary program..

A potential challenge to the identification strategy is posed by the introduction of a new upper secondary program in Sweden, the Technology program, at the same time as the curriculum reform in autumn 2000. The new program could potentially induce a different sample of students to enter the Social Science program after the reform. The introduction of the Technology program resulted in a drop in the fraction of males enrolling in the Social Science program. However, we show that this reduction was not systematic since students predetermined covariates balance before and after the reform.

\footnotetext{
${ }^{2}$ In Sweden, a student's school starting year is based on his or her calendar year of birth. The school starting age effect implies that students born in December differ from students born in January regardless of whether the reform was in place or not since school-wise they are one year younger than their January born peers. See for example Black et al. (2011) and Fredriksson and Öckert (2014) regarding the importance of the school starting age effect.

${ }^{3}$ We include students born in 1982-1983, 1984-1985, 1985-1986, 1986-1987 and 1987-1988.

${ }^{4}$ For a more detailed explanation of the Swedish upper secondary program system, see Section 2.

${ }^{5}$ The exact increase depends on the specialization track selected within the Social Science program.
} 
We begin the main analysis by investigating the impact of the reform on course-taking behavior in the Social Science program. In line with the aim of the more flexible curriculum, our suggest that the reform significantly altered students' course-taking behavior. We find a significant and large drop in mathematics attainment across males and females, by approximately 39 percent. The decrease was not offset by an increased enrollment in STEM- related courses. Rather, we find that students tend to substitute mathematics with non-STEM elective courses. However, when investigating the effect of the reform on tertiary education outcomes, we do not find a significant impact on the probability of completing tertiary education in a field that requires the pivotal mathematics course. Nor do we find an effect on the speed at which students enter tertiary education after graduating from upper secondary school. Taken together, these results suggest that students' educational prospects, on average, were not limited by the course choices they made under the more flexible curriculum.

On the contrary, our results suggest a positive impact of the curriculum reform on students' probability of enrolling in tertiary education. More exactly, we find an average increase of approximately 3.7 percent in this probability (statistically significant at the 1 percent level of significance). Furthermore, the reform led to an increase in the probability of exiting the tertiary studies with a degree. Splitting the sample by gender shows that the overall effect was driven by a large and positive impact on females, for whom we estimate a 6.5 percent increase in the probability of earning a tertiary degree. Our results are robust to both the choice of bandwidth and other coinciding school reforms. As the students in our sample are too young to allow us to study actual earnings, we instead estimate the impact on expected earnings based on field of study and gender ${ }^{6}$ We find no effect of the reform on students annual expected earnings.

We propose a possible transmission channel explaining the positive impact on tertiary education enrollment: an increase in GPA. After the reform, students could substitute courses they may find uninteresting or difficult, including the relatively difficult intermediate mathematics course, with courses of their own choice. We estimate a positive and significant impact of the reform on GPA. However, our results do not suggest that social science students out-compete students from other upper secondary programs in the admission process for tertiary education

\footnotetext{
${ }^{6}$ Students are 27 years old in the most recent data and the differential life cycle trajectories in earnings based on study choice are not yet materialized (Bhuller et al. 2017). Field of study is coded in detail and contains 116 education categories.
} 
after the reform. Hence, while the reform increased educational attainment among students in the Social Science program, it did not do so at the expense of a corresponding decrease in contemporary cohorts in the Natural Science or vocational programs. The most likely explanation is that the treated social science students enrolled in non-capacity constrained tertiary education fields

The heterogeneity analysis reveals mixed results with regard to treatment heterogeneity. We examine the distributional impact of the more flexible curriculum along the dimension of parents' socio-economic status (SES). Regarding SES, we find no evidence that relatively disadvantaged students were negatively affected by the reform. It rather seems that students in the lowest quartile benefitted the most from the more flexible curriculum. Furthermore, we investigate how the impact of the curriculum reform varies with the quartile of a student's final GPA from lower secondary school and find that the overall effect is primarily driven by a positive impact on students in the upper middle of the grade distribution.

We contribute to the existing literature on the impact of upper secondary school curriculum on tertiary education and labor market outcomes. The existing literature typically focuses on the effect of specific courses or subjects included in the course curriculum on subsequent outcomes, with a focus on mathematics and science Altonji, 1995, Levine and Zimmerman, 1995, Rose and Betts, 2004; Joensen and Nielsen, 2016; Sosa, 2016; Goodman, 2017; Görlitz and Gravert, 2018; Yu and Mocan, 2018; Ning, 2014). However, we differ in one major aspect: We estimate the effect of an increased choice set that allows students to choose courses based on personal preferences without putting any particular emphasis or value on the exact courses chosen. Of course, estimates of returns to particular subjects in upper secondary school are important and constitute valuable informative input for the design of the curriculum content, but they have little to say regarding the optimal level of rigidity in the course curriculum. Another contribution is the evaluation of a school reform that has never before been evaluated.

The paper most closely related to oursis a working paper by Yu and Mocan (2018). They investigate the causal effect of upper secondary school curriculum flexibility on student outcomes. The authors exploit a curriculum reform in China launched in 2004 that increased students' freedom when selecting courses. The authors find a positive impact on both students' academic achievement at university level and their mental well-being. However, the 
reform changed numerous aspects of the curriculum, so identifying the effect of the increased flexibility alone is not straightforward. In contrast to $\mathrm{Yu}$ and Mocan (2018), who measure outcomes for a representative sample of students while still in tertiary education, we have access to data on the entire student population in Sweden and are able to follow them up to the age of 27. Our rich data also allows for estimation of distributional effects. From the point of view of the social planner, knowing where and how in the distribution students react to more flexibility is vital information to ensure equity in educational opportunities.

The rest of the paper is structured as follows: Section 2 describes the details of the school reform and the institutional framework of the educational system in Sweden, Section 3 presents the identification strategy, Section 4 describes the data, and Section 5 presents and discusses the main results and heterogeneity analysis. In Section 6, we provide a range of robustness tests, and Section 7 concludes the paper.

\section{Institutional Background}

Attending upper secondary school is not required by Swedish law. Nevertheless, after completing nine years of compulsory education in Sweden, most students choose to continue their education in the Swedish upper secondary school system. In 1999 and 2000, approximately 98 percent of all compulsory school graduates entered upper secondary school in the same year (Skolverket, 2000; Skolverket, 2001).7 Without any grade retention or other discontinuities in prior education, students are expected to enter upper secondary school in the autumn semester of the year in which they turn 16 years old and then graduate after three years. Students apply for enrollment in specific upper secondary programs (e.g., a higher education preparatory program such as the Social Science program or the Natural Science program or a vocational program such as the Energy program or the Hotel, Restaurant and Catering program) and are admitted based on their grades from lower secondary school 8 In year 2000, the number of available national upper secondary school programs increased from 16 to 17 as a Technology program was officially introduced (Skolverket, 2000).

\footnotetext{
${ }^{7}$ Swedish compulsory education is divided into lower primary school (age 7-10), upper primary school (age 10-13) and lower secondary school (age 13-16). The reference list for references in Swedish is found in the Online appendix.

${ }^{8}$ The decision is made prior to lower secondary school graduation.
} 


\subsection{The Upper Secondary School Reform GY2000}

From 1994 to 2011, the Swedish upper secondary school curriculum was regulated by Lpf 94, although an important revision of the existing program structure and curricula was made as part of the GY2000 reform, implemented in year 2000. A main objective of the reform was to increase the share of elective coursework and therefore also the students' course choice flexibility, in particular in the Natural Science and Social Science programs, the Swedish government thought that the course plans for these two programs were too rigid (Skolverket, 1998; Prop.1997/98:169).

The GY2000 reform increased upper secondary school students' course choice, to various degrees, on existing upper secondary school programs. The percentage of upper secondary school credits devoted to mandatory courses decreased while credits devoted to choice based coursework increased mainly through the introduction of a new package of elective courses from which students choose a number of courses to fill a quota of credits (GY2000:19; GyVux 1994/97:17) $!^{9}$ While all Swedish upper secondary school programs were affected by the reform, this paper focuses on students enrolled in the Social Science program for the main analysis. The Social Science program is the most popular upper secondary program in Sweden, prior to the reform, the government raised concerns about the rather strict program curriculum. Before the reform social science students had a quota of 190 course credits, corresponding to 8.8 percent of the total credits, to obtain from individual course choices 10 In addition, students were offered some extra flexibility within two of the available specialization tracks within the Social Science program, Business Administration and Humanities, but no flexibility within the Social science track (GyVux 1994/95:14). After the reform the quota of credits to be earned from choice based course work differed between program tracks, ranging from 18-24 percent of total credits 11 With the exception of the course Mathematics C, described below,

\footnotetext{
${ }^{9}$ There are specialization tracks within some of the vocational programs that experienced a small decrease in elective coursework. Choice based coursework within the 15 vocational programs made up 14.9-56.1 percent of total credits prior the reform and 22-52 percent after the reform.

${ }^{10}$ The same figure applies to the Natural Science program.

${ }^{11}$ The number of credits allocated to individual choice increased to 300 credits, corresponding to 12 percent of total credits (total credits increased from 2150 to 2500). Among the specialization tracks, the quota of credits allocated to elective courses corresponded to 6-12 percent of the total course credits depending on which specialization track students chose to enroll in. For students in the Social Science track elective increased with an additional 300 credits (12 percent). Corresponding numbers were 200 credits ( 8 percent) for student in Business Administration and 150 credits (6 percent) for students enrolled in the Culture- and the Language tracks (GY2000:16). For the Natural Science program the quota of course credits allocated to the new elective package was 200 credits (8 percent) (GY2000:19).
} 
each school was to decide what electives to offer.

Another reason for focusing the analysis on students in the Social Science program is that one implication of the reform was that a full-year course in intermediate mathematics Mathematics $C$, was made elective as opposed to mandatory. That is, the course was moved from the mandatory course list to the package of elective courses (GY2000:16; GyVux 1994/97:16). Swedish media published articles informing about the increase in curriculum flexibility and the new Technology program, yet no information about the changes regarding the Mathematics $\mathrm{C}$ course seems to have been dispersed to the public 12 If students and parents were poorly informed about this change, this attenuates the risk of student sorting based on changes in mathematics requirements at the Social Science program. Prior to the reform, student were required to complete three mathematics courses, Mathematics A, B and C, corresponding to approximately 9.3 percent of the total amount of course credits ${ }^{13}$ After the reform, students were required to complete only the A- and B-level courses in mathematics, corresponding to 6 percent of the total amount of credits in the new curriculum. Although each upper secondary school was free to decide what electives to offer, Mathematics $\mathrm{C}$ was made an exception, so that after the reform all upper secondary schools were required to include this course in the elective course package offered to students in the Social Science program. The Swedish National Agency for Education (Skolverket) deemed mathematics as particularly important for tertiary education since courses in mathematics is a common entry requirement for many university programs (Skolverket, 1998). For example, the intermediate mathematics course Mathematics $\mathrm{C}$ is an entry requirement for popular undergraduate programs in business and economics at Swedish universities as well as for other university programs such as those for future architects and real estate agents (UHR, 2016; SACO, 2018).

A second feature of the GY2000 reform was the introduction of a new higher education preparatory program, the Technology program. Prior to the reform, the Natural Science program offered a technical specialization track. The aim of the new Technology program was to increase

\footnotetext{
${ }^{12}$ Tidningarnas Telegrambyrå (1999), "FAKTA: NYA GYMNASIESKOLAN",Tidningarnas Telegrambyrå, September 15; Anna Lena Wallström (1999), "Fler valmöjligheter för gymnasieelever", Borås Tidning, September 16, page 14; Inga-Lill Hagberg (1999), "GYMNASIEFÖRSLAG Teknik och miljö nya val", Svenska Dagbladet, September 16, page 4; Tidningarnas Telegrambyrå (1999), "BRÅTTOM ATT VÄLJA TILL FÖRÄNDRAT GYMNASIUM", Tidningarnas Telegrambyrå, November 4; Lena Hennel (1999), "Lärarkritik mot gymnasiereform", Svenska Dagbladet, November 5, page 5 ;Anna Asker(1999), "Nytt teknikprogram ska avhjälpa teknikerbristen", Svenska Dagbladet, December 7, page 30.

${ }^{13}$ Approximately 5.1 percent for Mathematics A, 1.9 percent for Mathematics B and 2.3 percent for Mathematics C (GyVux 1994/95:16).
} 
the supply of available programs for students interested in the natural sciences and technology since the government at the time deemed that the technical orientation within the current Natural Science program was not sufficient to meet the demand from students interested in technology (Prop.1997/98:169). While we are not explicitly interested in the introduction of the Technology program, it may have induced a different sample of students entering the Social Science program after the reform. In Section 3.1, we discuss this challenge for identification more thoroughly and then provide evidence in Section 5.1 that the introduction of the Technology program should not be of any significant concern.

\subsection{Course-taking Behavior}

A natural first question to ask is whether the reform influenced students' course-taking behavior. The increase in choice set would mechanically increase course participation in elective subjects since scope for choice was limited before the reform. However, when evaluating the impact of the reform, it is useful to know more exactly what subjects students chose when more flexibility is introduced. Figure 1 shows the enrollment rates in a selection of courses for students in the Social Science program before and after the reform 14 The STEM courses are courses traditionally associated with the natural sciences and the non-STEM courses belong in other fields 15 In line with the aim of the curriculum reform, Figure 1 suggests that the reform effectively altered students' course-taking behavior. Figure 1 shows increased enrollment in non-STEM classified courses. A large drop in Mathematics C enrollment can also be seen when the course was made elective, and this decrease is not offset by a corresponding increase in STEM courses. To rule out a general decrease in mathematics attainment, it is reassuring to see that enrollment in the Mathematics B, which continued to be mandatory for all students also after the reform, did not change. We can also note that even though Mathematics $\mathrm{C}$ was mandatory before the reform, not all students in the Social Science program enrolled the course. One anecdotal reason for this is that schools could require students who did not pass the preceding basic mathematics courses to re-take Mathematics A and B while their peers went on to take Mathematics C. These students then graduated from upper

\footnotetext{
${ }^{14}$ Appendix Figure A1 and A2 present enrollment rates by gender.

${ }^{15}$ The array of elective courses made available the reform is huge since each school had complete freedom to decide what courses to offer(besides Mathematics C). Therefore, in Figure 1 we have only included the sample of courses listed as recommended by the Swedish National Agency for Education (GY2000:16) that existed both before and after the reform. See Appendix Table A1 for a complete list of included courses.
} 
secondary school with a reduced number of credits due to not having taken Mathematics C. Before implementation of the new reform, experts raised concerns about making the Mathematics C course voluntary in the Social Science program and predicted that the reform would lead to a substantial decrease in mathematics attainment (Grevholm, 1999). We hypothesize that a decline in mathematics attainment due to substitution with other subjects under the more flexible course curriculum may play a central role as a mediator of the impact running from course-taking flexibility to students' tertiary education outcomes. In terms of identification, one important aspect is the fact that all upper secondary schools were required to offer Mathematics $\mathrm{C}$ in the elective course package. This implies that the drop in Mathematics $\mathrm{C}$ enrollment, presented in Figure 1, was not a result of a drop in the supply of the course but rather of a decrease in student demand (GY2000:16).
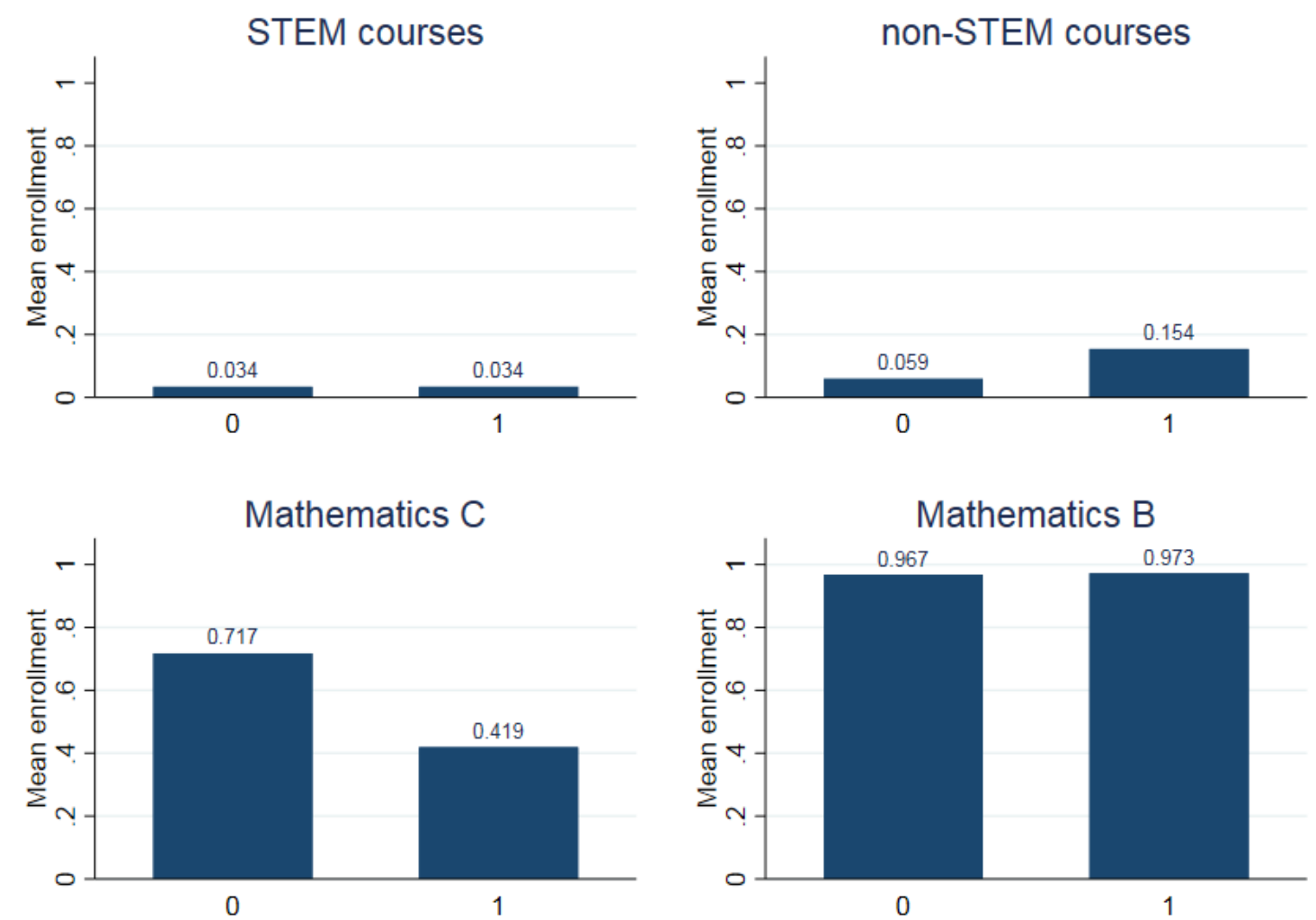

The figure presents enrollment means among social science students in the year before (0) and after the reform (1). STEM courses contain courses traditionally offered in the Natural Science program prior to the reform. For a detailed description of the courses in the STEM and non-STEM categories,see Appendix Table A1.

Figure 1: Students course-taking behavior 


\section{Empirical Strategy}

This study estimates the causal average impact of an upper secondary school curriculum reform on students' course taking behavior, tertiary education outcomes and annual expected earnings. We make use of the fact that students' birth dates decided whether they started upper secondary school when the curriculum was less flexible or after more flexibility was introduced in autumn 2000. We compare students born immediately to the right of the threshold, in January 1984 to students born precisely before, in December 1983. The intuition in a regression discontinuity framework is that students on each side of the threshold are similar and that the only difference in outcomes between them is due to the reform. Reform exposure is a deterministic function of age, measured in birth month and year, $B_{i}$. Let $R_{i c}$ be reform exposure. Then $R_{i c}=1\left\{B_{i} \geq c\right\}$, where $c$ is the cutoff month, equal to January 1984 . The treatment effect is the difference in outcomes at the cutoff between the treated cohort, born in or after $c$ and the control cohort, born before $c$ :

$$
\alpha_{R D}=\lim _{B \downarrow c} E\left[y_{i c} \mid B_{i}=b\right]-\lim _{B \uparrow c} E\left[y_{i c} \mid B_{i}=b\right] .
$$

Effectively, we estimate two regressions, one on each side of the threshold:

$$
y_{i c}=\delta+\lambda R_{i c}+\gamma f\left(B_{i}-c\right)+\beta f\left(B_{i}-c\right) R_{i c}+\theta \mathbf{X}_{i c}+\pi \mathbf{W}_{i c}^{p}+\eta_{m}+v_{i c} .
$$

The reform exposure, $R_{i c}$, is equal to 1 if individual $i$ was born in or after January 1984, $c$, and hence entered upper secondary school in year 2000 when the reform was implemented, and 0 if born before. Birth month and year, $B_{i}$, is normalized around the cutoff such that $c=0$. $\alpha_{R D}$ is estimated as $\hat{\lambda}$. First, we estimate the impact of the reform on course-taking behavior. Primarily, for the social science students we make sure that the behavior with regards to the choice of Mathematics $\mathrm{C}$ changed. $y_{i c}$ is Mathematics $\mathrm{B}$ and $\mathrm{C}$ enrollment and enrollment in STEM and non-STEM courses. We proceed to the main analysis, estimating the reform impact on tertiary education outcomes for student $i$ in cohort $c$. Here, $y_{i c}$ are several outcomes in tertiary education and annual expected earnings, as described in detail in Section 4.

In the regression analysis we include a vector of control variables similar to those used in related work (Kirkeboen et al., 2016; Malamud and Pop-Eleches, 2010, 2011). Adding controls 
improves precision and help us reduce any bias due to potential differences in pre-determined characteristics of individuals to the left and right of the cutoff. We add a vector of controls for pre-determined student characteristics $\mathbf{X}_{i c}$, including gender and an indicator variable equal to 1 if the individual obtained a grade of pass with distinction or special distinction in mathematics in lower secondary school. The lower secondary mathematics grade is included as a control for mathematics ability since we hypothesize that this ability is an important determinant of a student's choice of upper secondary courses, in particular whether to substitute the Mathematics $\mathrm{C}$ course for another course under the new flexible curriculum introduced as part of the reform. We include a vector of parent characteristics $\mathbf{W}_{i c}^{p}$, which contains information on whether at least one parent had a low level of education (defined as not having completed three years of upper secondary school), the earnings of the father averaged over age 14-16 of the child, and parents' immigration status (equal to 1 if both parents immigrated to Sweden). $\eta_{m}$ contains controls for municipality fixed effects, the level at which compulsory and upper secondary education is operated in Sweden. We also conduct a heterogeneity analysis to test whether the impact of the reform differs along lower secondary GPA as well as a socio-demographic dimension.

Split time trends $f($.$) are included to allow for different trends (slopes) before and after the$ reform. We estimate a local polynomial regression with a first-order polynomial as suggested by Gelman and Imbens (2018). The local linear regression will effectively estimate two regressions, one on each side of the threshold. We use a bandwidth of three months on each side and a triangular kernel since it is shown to be boundary optimal (Cheng et al., 1997). In practice, the choice of kernel should not significantly alter the results (Lee and Lemieux, 2010).

To capture the causal impact of the flexible curriculum, $\alpha_{R D}$, in the limit, individuals born in December 1983 must be identical to children born in January 1984 such that the only difference comes from curriculum regime. One concern is that birth month of students is correlated with, for example, educational attainment. Previous research has shown substantial differences in educational achievements depending on month of birth ${ }^{16}$ To account for the effect of school starting age, we follow the identification strategy in Carneiro et al. (2015) and Bertrand et al. (2019) and include cohorts born in neighboring non-reform cutoff years,

\footnotetext{
${ }^{16}$ See for example Fredriksson and Öckert 2014 ) and Black et al. (2011) for good examples of the importance of school starting age.
} 
1982-1983, 1984-1985, 1985-1986, 1986-1987 and 1987-1988, in order to estimate a difference in regression discontinuity model, the RD-DD. By including these non-reform cutoff years we can estimate discontinuities in the non-reform years between children born in OctoberDecember and January-March. Intuitively, the discontinuity at the cutoff in January 1984 will be a combination of the true effect of the reform and month of birth effects: $\alpha_{R D}=$ $\tau_{\text {reform }}+\tau_{b_{i}}$. Under the assumption that month of birth effects are stable across cutoff years and do not interact with the true reform effect (Carneiro et al., 2015), we can estimate the average discontinuities in outcomes for the four non-reform cutoff years: $\alpha_{R D_{\text {noreform }}}=\tau_{b_{i}}$. By subtracting $\alpha_{R D_{\text {noreform }}}$ from $\alpha_{R D}$, we cancel out the month of birth effect and leave only the true, unconfounded impact of the reform:

$$
\alpha_{R D-D D}=\alpha_{R D}-\alpha_{R D_{\text {noreform }}}=\left(\tau_{\text {reform }}+\tau_{b_{i}}\right)-\left(\tau_{b_{i}}\right)=\tau_{\text {reform }}
$$

As our running variable determining treatment, $B_{i}$ is discrete the model will be misspecified because the estimation strategy assumes continuity at the cutoff. As suggested by Lee and Card (2008), the standard errors are clustered on the discrete values of the running variable, in this case month of birth-year. Cattaneo (2018) notes that clustering will only work if the running variable is inherently continuous. Indeed, time of birth is a continuous variable but due to limited data access we only observe the discrete time of birth: birth date in month and year. Therefore, clustering at the level of the running variable will solve the misspecification problem (Lee and Card, 2008).

The choice of bandwidth is important and selected to balance bias and precision. The asymptotic properties of the RD ensure unbiasedness at the cutoff. Hence the RD is a local estimator and including observations far away from the cutoff may introduce a bias in the estimate (Calonico et al. 2014). Ideally, the process of choosing the optimal bandwidth should be data driven. However, since our running variable, i.e., birth year and month is discrete, our feasible choices of bandwidth are restricted. We include the same number of months for all years, both the reform cutoff years and the neighboring non-reform cutoff years. In the robustness analysis, we will expand and narrow the bandwidth and check the sensitivity of our results to the choice. 


\subsection{Identifying assumptions}

We will consistently estimate the intent-to-treat (ITT) under the crucial assumption that individuals are unable to precisely manipulate the running variable. Use of age-based discontinuities, such as date of birth as the running variable, is common (Lee and Lemieux, 2010), and due to the difference in time between when individuals were born and when they entered upper secondary school, we can be sure that the reform was unknown at the birth date 17 An alternative way of thinking of the assumption of no manipulation is that there should be smoothness around the cutoff for all other variables. Note that we will investigate educational outcomes and annual expected earnings of a restricted part of the full population, namely upper secondary social science students. If the curriculum reform itself, in particular the introduction of the Technology program, caused sorting of students into different upper secondary programs, the comparison between the student samples enrolled in the Social Science program before and after the reform is confounded by selection To investigate sorting, we estimate the effect of the reform on the probability of enrolling in the Social Science program through estimation of equation 1 . The dependent variable is a dummy variable equal to 1 if individual $i$ born in cohort $c$ enrolled in the Social Science program. We include the full student population in the analysis and further split the sample to investigate potential differences between girls and boys 18

We directly address the question of whether our sample of social science students is comparable before and after the reform by estimating the impact of the reform on observable pre-determined covariates:

$$
E\left[X_{i c}\right]=\alpha+\phi R_{i c}+g\left(B_{i}\right)+\delta f\left(B_{i}\right) R_{i c}+e_{i c}
$$

A change in the composition of students in the Social Science program after the reform will signal that the reform itself induced a sorting effect, i.e., the more flexible curriculum and the new Technology Program might have non-randomly shifted students across programs. This

\footnotetext{
${ }^{17}$ We include a histogram of the frequency of birth in the relevant years, see Appendix Figure A3. There is a strong seasonality in timing of birth but it is not systematically different across the relevant years.

${ }^{18}$ Boys are more likely than girls to enter the new Technology program. According to Appendix Table A2, the fraction of males in the Technology program was 91 percent in the first cohort after the program was introduced.
} 
would imply that our ITT estimates give us the combined effect of curriculum flexibility and selection stemming from a different cohort of students entering the Social Science program after the reform.

Naturally, selection can only be controlled for if the researchers observe the relevant sorting dimensions. While we cannot rule out selection on unobservables, the balancing test is a first step to test the assumption of identical treatment and control groups, absent treatment. In particular, mathematics ability may be a dimension of sorting after the reform. The Technology program offered students a new upper secondary school program with a mathematics intensity in between that of the Social Science and the Natural Science programs. Contrary to the Social Science program, Mathematics C was made compulsory in the new Technology program. Hence, if there is a systematic draw of students from the Social Science program to the Technology program after the reform, it should be along the margin of receiving pass with distinction or pass with special distinction in lower secondary mathematics 19 As shown in Table A2, the fraction of students with a high grade in mathematics from lower secondary school (high math ability) after the reform was 60 percent for student in the new Technology program and 47 percent for students in the Social Science program. For the Natural Science program, the figure was 89 percent. This suggests that mathematics ability, to the extent it is captured by grades in lower secondary school, among students in the Technology program falls in between the ability levels of the students in the Social Science program and those in the Natural Science programs. We could study higher mathematics margins, for example the fraction of students that obtained the highest mathematics grade. However, these students are expected to be found on the margin to the Natural Science program so it is unlikely to see a sorting effect. Reducing the relevant margin to include students who received a grade of pass in mathematics in lower secondary school would not be relevant either, since approximately 99 percent of students entering the Social Science program met this criterion.

Besides the effect of increased flexibility on course taking and selection, there are at least two other features of the reform that may be captured in the treatment effect, $\alpha_{R D-D D}$. The other two features will be part of the impact of the reform and for policy purposes it is desirable to

\footnotetext{
${ }^{19}$ As discussed above we have defined a control for high mathematics ability that takes the value of 1 if the student received a final grade of either pass with distinction ("VG") or pass with special distinction (" $M V G ")$ in lower secondary school and 0 if the student received a grade of pass ("G") or fail (" $I G$ "). We control for this throughout the analysis.
} 
disentangle the separate components as much as possible. First, if there is sorting the students who entered the Social Science program after the reform experienced a different peer group compared with those who entered the program before the reform. In particular, if a large fraction of males disappeared to the Technology program, the post-reform peer group was more female dominated than the pre-reform one 20 The students entering the Social Science program may come from different backgrounds if, for example, socio-demographic background is a factor in choice of upper secondary school program then the peer group will change along these dimensions as well. We address this feature by presenting the results separately for males and females since the respective reactions to a change in gender composition may differ.

Second, the quality of education may change after the reform. It is possible that the teachers responded to the reform for example by making Mathematics A and B, i.e., the only mandatory math courses, more advanced since they anticipated that these courses would be the most advanced mathematics the majority of the students would ever take after Mathematics $\mathrm{C}$ became an elective. Alternatively, they may have made these courses easier to encourage a larger fraction of students to choose Mathematics $\mathrm{C}$ as an elective. It is difficult to separate this channel from the overall reform impact. We investigate whether students' grade point average (GPA) was affected by the reform. Such an effect can be driven either by course substitution or quality changes. We show, descriptively, the distribution of grades in the mathematics course prior to Mathematics C for all programs. Since the course is mandatory in all upper secondary school students, a different pattern for social science students compared with students in other programs suggest that teachers respond to the drop in mandatory mathematics by changing the quality of the course.

\section{Data}

We use Swedish registry data provided by Statistics Sweden. Statistics Sweden links several administrative registers by personal identification numbers and we obtained information about individuals' birth month and year, educational attainment, school grades and field of study in upper secondary school as well as in tertiary education. We link our individuals to their parents

\footnotetext{
${ }^{20}$ Our data show that 9 out of 10 students in the Technology program were males in the first school year after the reform, Appendix Table A2.
} 
(biological or adoptive) and we have information on the parents' background characteristics. Our data set contains the entire population of individuals born in Sweden between January 1982- December 1988 who have completed an upper secondary school program. We restrict our main sample to contain upper secondary school graduates from the Social Science program.

\subsection{Variables}

The outcome variables of interest are several measures of tertiary education and annual expected earnings. The outcome variables concerning tertiary education are measured at age 27 , as this is the oldest age at which we can observe this information in the dataset. The tertiary education outcomes comprise a set of binary and discrete variables capturing educational attainment on both the extensive and the intensive margin.

For impacts on the intensive margin, we construct an indicator variable, $M a C$-field, which is equal to 1 if an individual has her or his highest attained education in the field of business, economics, architecture or real estate management. Entry to all of these university programs requires prior completion of Mathematics $\mathrm{C}$ in upper secondary school 21 Inclusion of this outcome variable is motivated by its direct dependence on students' mathematics choices in upper secondary school.

Table 1: Mathematics $\mathrm{C}$ choice

\begin{tabular}{l|l|l} 
& High Returns & Low Returns \\
\hline Enroll & $(1)+$ & $(2)-$ \\
\hline Not enroll & $(3)-$ & $(4)+$ \\
\hline
\end{tabular}

Given students' potential returns to mathematics studies, one could roughly define one group of students who should (high returns) enroll in the Mathematics C course and one group who should not (low returns). A strict, non-flexible, course curriculum ensures that all students with potentially high returns enroll in the course, but it also forces students with low returns to take the course even if they would be better off studying something else; cells (1) and (2) in Table 1. Introducing choice under a flexible curriculum may lead to the desirable outcome that

\footnotetext{
${ }^{21}$ Obviously, there are other university fields, for example in the natural sciences, that also require Mathematics $\mathrm{C}$ or more. However, graduating from the upper secondary Social Science program does not make individuals eligible for these fields independent of whether they chose to take Mathematics C. Hence, the course choice is not pivotal for eligibility, in contrast to the fields of study included in $M a C$-field.
} 
low-return students opt out, i.e., cell (4), while high-return students continue to enroll, i.e., cell (1). If this is the case, we expect no impact of the reform on the outcome variable $\mathrm{MaC}$ field. However, introducing choice raises the concern that students with low potential returns who ideally should not enroll in the course continue to do so, i.e., cell (2). An even greater concern is that students with potentially high returns may refrain from taking the course under the flexible curriculum, i.e., cell (3), and forego the eligibility to enter mathematicsintensive post-secondary academic fields they would have pursued absent the reform. Under such circumstances we expect to find a negative impact on $M a C$-field.

We also include a discrete variable, Speed, measuring the speed at which the individuals enter tertiary education. The variable ranges from 0 to 5 . It is equal to 0 if an individual started tertiary education in the same year as she or he graduated from upper secondary school and 5 if she or he started tertiary education five years after completing upper secondary school ${ }^{22}$ We expect to find an impact here if students regret their choices induced by the reform and therefore have to take adult education classes to gain the desired eligibility for certain study fields in tertiary education.

For general tertiary education outcomes, we have constructed the indicator variable AnyTE, which is equal to 1 if the individual ever attended any tertiary education, and 0 otherwise to capture the impact of the reform on the extensive margin. We further include the indicator variable Degree, which is equal to 1 if an individual exited tertiary education with an academic or vocational degree. This variable does not distinguish between the different durations of tertiary education programs needed to earn a certain degree.

Given the time span of our data, the students are too young for us to study actual earnings (Bhuller et al. 2017). Students born in 1988 are at most 27 years old in the most recent data - an age at which the differential life cycle trajectories in earnings based on study choice have not yet materialized. Instead, we estimate the impact on expected earnings based on field of tertiary education and gender. To estimate the impact of the reform on expected returns to education, we impute an outcome variable for an individual's annual expected earnings in middle age. We take the average earnings for individuals aged $43-45$ in 2015, stratified

\footnotetext{
${ }^{22}$ We cannot extend the time to more than five years due to data restrictions. However, approximately 50 percent of graduating upper secondary students in Sweden enter university within five years (Holmlund et al. 2007). Note that this is a lower bound since less than 100 percent of students ever enter university.
} 
by gender and detailed information on field of tertiary education 23 We impute this value to the individuals in the relevant sample as the annual expected mean income, in Swedish kronor (SEK). We further stratify by level of education, in addition to field and gender, to capture the quantity of tertiary education in a separate measure of annual expected earnings. Table 2 summarizes the mean and standard deviation of the main variables for the sample of upper secondary social science students born in the pre- and post-reform years 1983 and 1984, respectively.

\begin{tabular}{|c|c|c|c|c|c|c|}
\hline & \multicolumn{3}{|c|}{ Before reform cohort 1983} & \multicolumn{3}{|c|}{ After reform cohort 1984} \\
\hline & Mean & Std. dev & Obs. & Mean & Std. dev & Obs. \\
\hline \multicolumn{7}{|l|}{ Tertiary Education Outcomes } \\
\hline Math C-field & 0.17 & 0.38 & 17402 & 0.17 & 0.38 & 17370 \\
\hline Speed & 2.54 & 1.26 & 11460 & 2.59 & 1.27 & 11660 \\
\hline Any tertiary education & 0.68 & 0.47 & 18470 & 0.69 & 0.46 & 18377 \\
\hline Degree & 0.34 & 0.47 & 18470 & 0.37 & 0.48 & 18377 \\
\hline \multicolumn{7}{|l|}{ Labor Market Outcome } \\
\hline Annual expected earnings (SEK) & 313275 & 107742 & 18470 & 314037 & 105577 & 18379 \\
\hline \multicolumn{7}{|l|}{ Upper Secondary School } \\
\hline GPA & 14.30 & 2.83 & 17006 & 14.55 & 2.94 & 17185 \\
\hline Mathematics $\mathrm{C}$ enrollment & 0.72 & 0.45 & 19098 & 0.42 & 0.49 & 19021 \\
\hline Mathematics B enrollment & 0.97 & 0.18 & 19098 & 0.97 & 0.16 & 19021 \\
\hline STEM enrollment & 0.03 & 0.18 & 19098 & 0.03 & 0.18 & 19021 \\
\hline Non-STEM enrollment & 0.06 & 0.24 & 19098 & 0.15 & 0.36 & 19021 \\
\hline \multicolumn{7}{|l|}{ Background Characteristics } \\
\hline High math ability & 0.46 & 0.50 & 18954 & 0.47 & 0.50 & 18867 \\
\hline Male & 0.37 & 0.48 & 19098 & 0.35 & 0.48 & 19021 \\
\hline Immigrant & 0.12 & 0.32 & 18023 & 0.13 & 0.33 & 17910 \\
\hline LowEducation $_{p}$ & 0.64 & 0.48 & 17860 & 0.62 & 0.48 & 17766 \\
\hline LogAvgWage & 11.00 & 3.81 & 18153 & 11.07 & 3.76 & 18076 \\
\hline
\end{tabular}

Table 2: Summary statistics for the Social Science Program

As can be seen in Table 2, before the reform, 72 percent of social science students took Mathematics C. After the reform, the share shrunk to 42 percent. Both before and after the reform, 17 percent of the students attained their highest level of education in a field that required Mathematics $\mathrm{C}$ for eligibility. Slightly less than 70 percent of the students enrolled in any tertiary education both before and after the reform, and 34 percent of the students who started upper secondary school before the reform went on to complete a higher education degree, immediately or at a later point, while the figure for those who started upper secondary school after the reform was 37 percent. The mean of speed to enter tertiary

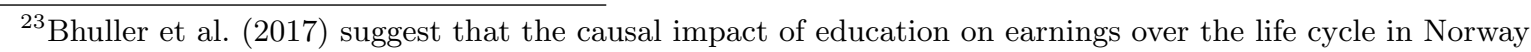
peak around age 45 . Our data includes 116 detailed tertiary education fields.
} 
education is approximately 2.5 years for both groups, which implies that the average student enters tertiary education 2-3 years after graduating from upper secondary school. The fraction of males in the sample is approximately 37 percent before and 35 percent after the reform. The low fraction of males can be explained by the fact that the analysis is restricted to students in the Social Science program, which traditionally has had a high share of female students. Around 46-47 percent of the students had a final grade of more than pass (i.e., pass with distinction or pass with special distinction) in mathematics from lower secondary school. Parent characteristics are similar in both groups.

\section{Results}

\subsection{Sorting}

As discussed in Section 2, the reform introduced a third higher education preparatory program. To separate the effect of increased course flexibility from the effect of the introduction of the new program, we must find out whether the sample of students in the Social Science program was similar in terms of background characteristics before and after the reform. We estimate the impact of the reform on the probability of enrolling in the Social Science program, using both the RD and the RD-DD estimator. Recall that the difference between the two is that the RD-DD is augmented with neighboring non-reform years to enable us to subtract a possible month of birth effect from the reform effect. Note that the entire population of upper secondary school students is included in this estimation. We also estimate the regression separately by gender since the new Technology program is strongly male dominated 24

The results in Table 3 reveal that the introduction of the Technology program indeed affected the probability of students choosing the Social Science program, at least for males 25 The pairwise difference across columns is the inclusion of control variables. In the RD-DD specification, the results are robust with respect to inclusion of different controls. The impact on the probability of choosing the Social Science program among the entire population of

\footnotetext{
${ }^{24}$ As seen in the extended summary statistics in Appendix Table A2, 91 percent of the students in the Technology program were males.

${ }^{25}$ Regression results of the impact of the introduction of the Technology program on other upper secondary programs than Social Science are presented in Appendix Table A3.
} 
female students is insignificant, as is evident in columns 3 and $4{ }^{26}$ Regarding male students, the comparison between $\mathrm{RD}$ and RD-DD estimates reveals that there is no seasonality in the decision to choose the Social Science program after the reform. In other words, males born in December and January are on average comparable when it comes to this decision. After the reform, males were on average 18 percentage points less likely to choose the Social Science program. In relative terms, the fraction of male students was 9 percent smaller after the reform.

Table 3: Probability of enrolling in Social Science

\begin{tabular}{lcccc}
\hline Social Science & RD & RD & RD-DD & RD-DD \\
\hline \multicolumn{5}{c}{ All } \\
Reform & $0.010^{* * *}$ & $0.006^{* *}$ & $-0.005^{* *}$ & $-0.006^{* * *}$ \\
Standard Error & 0.002 & 0.002 & 0.002 & 0.002 \\
Observations & 30,667 & 30,667 & 184,852 & 184,852 \\
\hline$R^{2}$ & 0.034 & 0.081 & 0.031 & 0.073 \\
Pre-reform Mean & 0.272 & 0.272 & 0.272 & 0.272 \\
\hline \multicolumn{5}{c}{ Females } \\
Reform & $0.041^{* * *}$ & $0.030^{* * *}$ & 0.008 & 0.007 \\
Standard Error & 0.003 & 0.003 & 0.006 & 0.006 \\
Observations & 15,128 & 15,128 & 91,119 & 91,119 \\
\hline$R^{2}$ & 0.046 & 0.063 & 0.036 & 0.057 \\
Pre-reform Mean & 0.351 & 0.351 & 0.351 & 0.351 \\
\hline \multicolumn{5}{c}{ Males } \\
Reform & $-0.019^{* * *}$ & $-0.019^{* * *}$ & $-0.017^{* * *}$ & $-0.018^{* * *}$ \\
Standard Error & 0.004 & 0.003 & 0.005 & 0.005 \\
Observations & 15,539 & 15,539 & 93,733 & 93,733 \\
\hline$R^{2}$ & 0.049 & 0.061 & 0.038 & 0.050 \\
Pre-reform Mean & 0.194 & 0.194 & 0.194 & 0.194 \\
\hline Controls & \multicolumn{5}{c}{$\checkmark$}
\end{tabular}

The table reports the impact of the reform on the probability of enrolling in the Social Science program for the full universe of upper secondary students. The first two columns show the RD regression results using a

3 -month bandwidth on each side of the cutoff and a triangular kernel. The discontinuity in outcomes is estimated with a local linear regression with separate trends on each side of the cutoff. We present the RD-DD estimates where we augment the regression with students born in October-March in the neighboring non-reform years 1982-1983, 1984-1985, 1985-1986, 1986-1987, and 1987-1988. The pairwise difference across columns is the inclusion of control variables.

The loss of boys poses a threat to the identification unless the loss is a random draw from the male population. ${ }^{27}$ Therefore, it is crucial to address whether the sample selection led to

\footnotetext{
${ }^{26}$ However, the pairwise comparison between the RD and RD-DD estimates reveals a large school starting age effect for female students.

${ }^{27}$ If males are systematically drawn from the Social Science program based on pre-determined characteristics, our estimates will be confounded by student sorting.
} 
a compositional change among the students enrolled in the Social Science program. For any $\mathrm{RD}$ design to be credible, i.e., to separate the treatment effect from any effects of the change in composition, we need to investigate the impact of the reform on pre-determined covariates. For any RD-design to be credible, i.e. to separate the treatment effect from the compositional change, we need to investigate the impact of the reform on pre-determined covariates.

Table 4: Balancing test of pre-treatment characteristics

\begin{tabular}{|c|c|c|c|c|c|}
\hline & $\begin{array}{c}\text { HighMath }_{i} \\
\text { (1) }\end{array}$ & $\begin{array}{c}\text { Male }_{i} \\
(2)\end{array}$ & $\begin{array}{c}\text { Loweduc } c_{p} \\
(3)\end{array}$ & $\begin{array}{c}\text { Foregin }_{p} \\
(4)\end{array}$ & $\begin{array}{c}\operatorname{Ln} \overline{\text { Earnings }}_{f} \\
(5)\end{array}$ \\
\hline \multicolumn{6}{|c|}{ All } \\
\hline RD-DD & -0.016 & $-0.024^{* * *}$ & -0.003 & -0.005 & -0.048 \\
\hline Standard Error & 0.012 & 0.009 & 0.012 & 0.003 & 0.054 \\
\hline Observations & 48,459 & 48,459 & 48,459 & 48,459 & 48,459 \\
\hline Pre-reform Mean & 0.456 & 0.360 & 0.630 & 0.110 & 11.146 \\
\hline \multicolumn{6}{|c|}{ Females } \\
\hline RD-DD & $-0.019 *$ & & -0.005 & -0.005 & 0.045 \\
\hline Standard Error & 0.011 & & 0.015 & 0.005 & 0.062 \\
\hline Observations & 30,830 & & 30,830 & 30,830 & 30,830 \\
\hline Pre-reform Mean & 0.481 & & 0.654 & 0.108 & 11.070 \\
\hline \multicolumn{6}{|c|}{ Males } \\
\hline RD-DD & -0.006 & & -0.002 & -0.004 & -0.149 \\
\hline Standard Error & 0.019 & & 0.016 & 0.005 & 0.115 \\
\hline Observations & 17,629 & & 17,629 & 17,629 & 17,629 \\
\hline Pre-reform Mean & 0.412 & & 0.586 & 0.113 & 11.281 \\
\hline
\end{tabular}

The table reports the impact of the reform on pre-determined characteristics: high mathematics grade in lower secondary school, gender, whether at least one parent has low education (i.e., not completed three years of upper secondary school), if both parents have immigrated, and average earnings of the father. We show the RD-DD estimates where we augment the regression with students born in October-March in the neighboring non-reform years 1982-1983, 1984-1985, 1985-1986, 1986-1987, and 1987-1988. The discontinuity in outcomes is estimated with a local linear regression with separate trends on each side of the cutoff.

The results in Table 4 are estimated separately for males and females since we want to separate the sample selection (loss in fraction of males) from the sample composition with respect to other characteristics. The results from the RD estimation can be found in Table A4. They reveal a strong selection on the mathematics grade in lower secondary school ${ }^{28}$ However, from Table 4 it is clear that in our preferred specification, the RD-DD, we have no such selection suggesting that the RD was picking up school starting age effects.29 We interpret this as

\footnotetext{
${ }^{28}$ In Appendix Table A5, we present an additional balancing test of pre-determined characteristics for the full population of upper secondary students

${ }^{29}$ In particular with respect to controlling for final lower secondary grade in mathematics. For example, McEwan and Shapiro (2008) show that test scores are significantly affected by school starting age.
} 
evidence of school starting age effects that will confound the RD-estimates and a comparison of children born in January to children born in December. Henceforth we present only the RD-DD estimates in the main analysis. All corresponding RD-estimates are available upon request.

Besides gender, the results in Table 4 suggest no evidence of a compositional change since the covariates balance before and after the reform. The only exception is the marginally significant decrease in female students with high math ability. The effect is small and significant only at the 10 percent level. However, in Table 3 we estimated no impact on the probability of enrolling in the Social Science program for females. Hence, this is of less concern relative to a potential non-random loss of males. In sum, besides the change in gender composition, we cannot reject that there was no systematic selection to the Technology program, with respect to the other observable characteristics. One possible explanation is that the loss of males was a random draw from the Social Science program.

\subsection{Course-taking Behavior}

Did the increase in course selection flexibility significantly alter social science students' coursetaking pattern? Table 5 presents the regression estimates corresponding to the descriptive results presented in Figure 1. The pairwise difference across columns is the inclusion of control variables. Even though the control variables increase $R^{2}$, they make little difference to the point estimates. 
Table 5: Course-taking behavior

\begin{tabular}{|c|c|c|c|c|c|c|c|c|}
\hline & $\begin{array}{l}\mathrm{MaC} \\
(1)\end{array}$ & $\begin{array}{l}\mathrm{MaC} \\
(2)\end{array}$ & $\begin{array}{c}\mathrm{MaB} \\
(3)\end{array}$ & $\begin{array}{c}\mathrm{MaB} \\
(4)\end{array}$ & $\begin{array}{c}\text { STEM } \\
(5)\end{array}$ & $\begin{array}{l}\text { STEM } \\
\quad(6)\end{array}$ & $\begin{array}{c}\text { non-STEM } \\
(7)\end{array}$ & $\begin{array}{c}\text { non-STEM } \\
(8)\end{array}$ \\
\hline \multicolumn{9}{|c|}{ All } \\
\hline RD-DD & $-0.288^{* * *}$ & $-0.284^{* * *}$ & $0.005^{*}$ & $0.005^{*}$ & 0.002 & 0.002 & $0.088^{* * *}$ & $0.087 * * *$ \\
\hline S.E. & 0.011 & 0.010 & 0.003 & 0.003 & 0.003 & 0.003 & 0.006 & 0.006 \\
\hline Observations & 48,459 & 48,459 & 48,459 & 48,459 & 48,459 & 48,459 & 48,459 & 48,459 \\
\hline$R^{2}$ & 0.120 & 0.211 & 0.023 & 0.040 & 0.045 & 0.046 & 0.119 & 0.123 \\
\hline Pre-reform $\bar{y}$ & 0.726 & 0.726 & 0.971 & 0.971 & 0.032 & 0.032 & 0.061 & 0.061 \\
\hline \multicolumn{9}{|c|}{ Females } \\
\hline RD-DD & $-0.279 * * *$ & $-0.274^{* * *}$ & 0.001 & 0.001 & 0.002 & 0.002 & $0.088^{* * *}$ & $0.087^{* * *} *$ \\
\hline S.E. & 0.013 & 0.012 & 0.002 & 0.002 & 0.003 & 0.003 & 0.006 & 0.006 \\
\hline Observations & 30,830 & 30,830 & 30,830 & 30,830 & 30,830 & 30,830 & 30,830 & 30,830 \\
\hline$R^{2}$ & 0.115 & 0.207 & 0.025 & 0.044 & 0.057 & 0.058 & 0.130 & 0.133 \\
\hline Pre-reform $\bar{y}$ & 0.715 & 0.715 & 0.971 & 0.971 & 0.034 & 0.034 & 0.058 & 0.058 \\
\hline \multicolumn{9}{|c|}{ Males } \\
\hline RD-DD & $-0.302^{* * *}$ & $-0.300 * * *$ & $0.012^{* *}$ & $0.012^{* *}$ & 0.003 & 0.003 & $0.088^{* * *}$ & $0.088^{* * *}$ \\
\hline S.E. & 0.014 & 0.011 & 0.006 & 0.005 & 0.006 & 0.006 & 0.011 & 0.011 \\
\hline Observations & 17,629 & 17,629 & 17,629 & 17,629 & 17,629 & 17,629 & 17,629 & 17,629 \\
\hline$R^{2}$ & 0.148 & 0.238 & 0.036 & 0.049 & 0.044 & 0.047 & 0.113 & 0.125 \\
\hline Pre-reform $\bar{y}$ & 0.745 & 0.745 & 0.970 & 0.970 & 0.030 & 0.030 & 0.066 & 0.066 \\
\hline Controls & & $\checkmark$ & & $\checkmark$ & & $\checkmark$ & & $\checkmark$ \\
\hline
\end{tabular}

The table reports the impact of the reform on enrollment in selected courses: Mathematics C, Mathematics B, STEM courses (i.e., courses in science, technology, engineering, and mathematics), and non-STEM courses. We present the RD-DD estimates where we augment the regression with students born in October-March in the neighboring non-reform years 1982-1983, 1984-1985, 1985-1986, 1986-1987, and 1987-1988. The discontinuity in outcomes is estimated with a local linear regression with separate trends on each side of the cutoff, using a 3-month bandwidth on each side of the cutoff and a triangular kernel. The pairwise difference across columns is the inclusion of control variables.

As is evident from Table 5, the reform did have a significant impact on students' course-taking behavior. In particular, there was considerable substitution of Mathematics $\mathrm{C}$ after the reform. That is, we find a highly statistically significant post-reform decrease in the fraction of students enrolled in this course ${ }^{30}$ The estimates suggest a decrease by 28.4 percentage points after the reform, approximately equivalent to a 39 percent decrease given the pre-reform enrollment rate of 72.6 percent. The point estimate differs only marginally across genders: compared with the baseline, females were 38 percent less likely to take Mathematics $\mathrm{C}$ after the reform; the corresponding decrease for males was 40 percent. Adding controls for pre-determined

\footnotetext{
${ }^{30}$ Our register data contains a complete list of grades from each course in upper secondary school and we define attainment as having a grade from Mathematics C. The actual grade does not matter, so students who received a failing grade for the course are still defined as having attained the course.
} 
characteristics in column 4 barely affects the magnitude of the coefficient estimates.

To ensure that this drop is not driven by a general decline in mathematics attainment, we also estimate the impact on the preceding math course, Mathematics B. There is a small increase in the probability of enrolling in Mathematics B after the reform, driven by males. However, the course was mandatory both before and after the reform and relative to the baseline of 97.1 percent, the estimated increase corresponds to 0.5 percent, which can be compared with the drop in completion of Mathematics C by 39 percent. More course choice flexibility did not increase students' probability of enrolling in STEM related courses. Instead, under the flexible curriculum, students chose to enroll in non-STEM courses such as arts and humanities and media. We estimate an 8.7 percentage point increase in the probability of enrolling in non-STEM courses after the reform, which is approximately equivalent to a 143 percent increase given the pre-reform mean of 6.1 percent. From Table 5, we conclude that the students experienced a large decrease in mathematics attainment and, importantly, this was not compensated by selecting other STEM-related courses.

\subsection{Tertiary Education Outcomes and Expected Earnings}

Next, we proceed to estimate the impact of the reform on tertiary educational outcomes and annual expected earnings for students in the Social Science program. 
Table 6: Tertiary education outcomes

\begin{tabular}{lcccccccc}
\hline & MaC-field & MaC-field & Speed & Speed & Any TE & Any TE & Degree & Degree \\
& $(1)$ & $(2)$ & $(3)$ & $(4)$ & $(5)$ & $(6)$ & $(7)$ & $(8)$ \\
\hline & & & All & & & & & \\
RD-DD & -0.007 & -0.004 & 0.016 & 0.017 & $0.026^{* * *}$ & $0.025^{* * *}$ & $0.016^{*}$ & $0.014^{*}$ \\
Standard Error & 0.006 & 0.005 & 0.029 & 0.027 & 0.009 & 0.007 & 0.009 & 0.008 \\
Observations & 44,122 & 44,122 & 29,825 & 29,825 & 47,006 & 47,006 & 47,006 & 47,006 \\
\hline$R^{2}$ & 0.015 & 0.040 & 0.026 & 0.048 & 0.020 & 0.112 & 0.020 & 0.079 \\
Pre-reform mean & 0.178 & 0.178 & 2.559 & 2.559 & 0.675 & 0.675 & 0.333 & 0.333 \\
\hline & & & Females & & & & & \\
RD-DD & -0.006 & -0.004 & 0.043 & 0.037 & $0.020^{* *}$ & $0.023^{* * *}$ & $0.023^{* * *}$ & $0.025^{* * *}$ \\
Standard Error & 0.009 & 0.008 & 0.030 & 0.028 & 0.008 & 0.007 & 0.008 & 0.008 \\
Observations & 28,438 & 28,438 & 20,651 & 20,651 & 29,878 & 29,878 & 29,878 & 29,878 \\
\hline$R^{2}$ & 0.016 & 0.034 & 0.032 & 0.048 & 0.023 & 0.091 & 0.026 & 0.059 \\
Pre-reform mean & 0.168 & 0.168 & 2.493 & 2.493 & 0.729 & 0.729 & 0.384 & 0.384 \\
\hline & & & Males & & & & & \\
RD-DD & -0.008 & -0.006 & -0.032 & -0.024 & 0.028 & $0.029^{*}$ & -0.008 & -0.007 \\
Standard Error & 0.008 & 0.008 & 0.068 & 0.066 & 0.020 & 0.017 & 0.015 & 0.013 \\
Observations & 15,684 & 15,684 & 9,174 & 9,174 & 17,128 & 17,128 & 17,128 & 17,128 \\
\hline$R^{2}$ & 0.039 & 0.064 & 0.042 & 0.059 & 0.033 & 0.110 & 0.025 & 0.061 \\
Pre-reform mean & 0.196 & 0.196 & 2.715 & 2.715 & 0.580 & 0.580 & 0.245 & 0.245 \\
\hline Controls & & $\checkmark$ & & $\checkmark$ & & $\checkmark$ & & $\checkmark$
\end{tabular}

The table reports the impact of the reform on tertiary education outcomes. We present the RD-DD estimates where we augment the regression with students born in October-March in the neighboring non-reform years 1982-1983, 1984-1985, 1985-1986, 1986-1987, and 1987-1988. The discontinuity in outcomes is estimated with a local linear regression with separate trends on each side of the cutoff, using a 3-month bandwidth on each side of the cutoff and a triangular kernel. The pairwise difference across columns is the inclusion of control variables.

Table 6 presents the impact of the schooling reform on tertiary education outcomes. The RD-DD approach enables us to disentangle the school starting age effect on $y_{i}$ from the unconfounded effect of the reform, under the mild assumption that school starting age effects are constant across the neighboring cutoff years (Carneiro et al., 2015). This assumption cannot be explicitly tested but we complement the analysis with an $\mathrm{RD}$ regression identical to equation 1 for all of our control years 31 The point estimates on tertiary education variables for preand post-reform control years have similar magnitudes. The control cutoff prior to the reform has a slightly higher point estimate for the probability of obtaining a degree, relative to the control cutoffs after the reform. However, this leads to an underestimation of the magnitude of the RD-DD estimate.

\footnotetext{
${ }^{31}$ The RD estimate per control year is plotted in Appendix Figure A4.
} 
We estimate no impact of the reform on the students' probability of choosing a field in tertiary education that requires Mathematics $\mathrm{C}$ for eligibility (columns 1 and 2). The result might indicate that students opting out of Mathematics C under the flexible curriculum were students who would not have continued their academic career in fields where the course is pivotal under a strict curriculum where the course was mandatory. Nor do we find a clear effect on the speed of entering higher education after graduating from upper secondary school (columns 3 and 4). We hypothesized that we would find an impact on these two variables if students opted out of mathematics under the flexible curriculum and then regretted their choice when transferring to the tertiary education cycle. However, the results do not support this hypothesis.

We find a positive and statistically significant effect of the reform on the probability of attending tertiary education (columns 5 and 6 ). The estimated size of the effect is robust to the inclusion of controls. The control variables are included for two reasons: first, to increase precision, and secondly, they allow us to assess the possible presence of a sorting bias based on observable characteristics. Adding the control variables increases the explained variation in outcomes, $R^{2}$, but does not significantly alter the magnitude of the point estimates. Even though our results show that the loss of males in the Social Science program is not systematic, based on observable characteristics, we present the results separately for males and females. If females and males responded differently to a more flexible curriculum and/or to the larger share of female peers in the program after the reform, the estimates are expected to differ. We estimate, on average, a 2.5 percentage point increase in the probability of enrolling in tertiary education, which is equivalent to a 3.7 percent increase given the pre-reform mean of 67.5 percent. Males have a larger point estimate, which is significant at the ten percent level (column 4). Relative to their respective baselines, the reform induced a 3.2 percent increase in the probability of enrolling in tertiary education for females while the corresponding increase for males is 5 percent. The precision decreases when splitting the sample in half.

The reform also led to an increase in the probability of exiting tertiary education with a degree (columns 7 and 8). For the full sample, the increase is only marginally significant, but as is evident when splitting the sample by gender, females drive the increase in the probability of earning a degree. After the reform, females were 6.5 percent more likely to exit the tertiary education cycle with a degree. 
Taken together, the results regarding the effect of the reform on tertiary education outcomes show a positive impact on students' probability of entering tertiary education. The increase in tertiary education enrollment translates into a higher fraction of students earning a degree. Our results show that the impact is mainly driven by a positive impact on females, which may signal that they benefit more than males from a flexible curriculum and/or from being in an even more female-dominated group of peers.

We proceed by estimating the impact of the reform on expected earnings in middle age 32

Table 7: Earning Outcomes

\begin{tabular}{|c|c|c|c|c|c|c|}
\hline & $\begin{array}{c}E[\text { Earnings }]_{f} \\
(1)\end{array}$ & $\begin{array}{c}E[\text { Earnings }]_{f} \\
(2)\end{array}$ & $\begin{array}{c}E\left[\text { Earnings }_{f l}\right. \\
(3)\end{array}$ & $\begin{array}{c}E\left[\text { Earnings }_{f l}\right. \\
(4)\end{array}$ & $\begin{array}{c}\text { Earnings }_{30} \\
(5)\end{array}$ & $\begin{array}{c}\text { Earnings }_{30} \\
(6)\end{array}$ \\
\hline \multicolumn{7}{|c|}{ All } \\
\hline RD-DD & 0.004 & $0.011^{* *}$ & -0.001 & 0.007 & -0.040 & -0.027 \\
\hline S.E. & 0.006 & 0.005 & 0.005 & 0.005 & 0.027 & 0.023 \\
\hline$N$ & 47,006 & 47,006 & 46,971 & 46,971 & 25,444 & 25,444 \\
\hline$R^{2}$ & 0.021 & 0.158 & 0.021 & 0.143 & 0.003 & 0.014 \\
\hline $\bar{y}$ & 12.595 & 12.595 & 12.621 & 12.621 & 12.011 & 12.011 \\
\hline \multicolumn{7}{|c|}{ Females } \\
\hline RD-DD & 0.006 & 0.008 & 0.002 & 0.005 & -0.008 & -0.009 \\
\hline S.E. & 0.007 & 0.006 & 0.006 & 0.005 & 0.020 & 0.018 \\
\hline$N$ & 29,878 & 29,878 & 29,858 & 29,858 & 16,288 & 16,288 \\
\hline$R^{2}$ & 0.024 & 0.100 & 0.025 & 0.103 & 0.018 & 0.027 \\
\hline $\bar{y}$ & 12.535 & 12.535 & 12.561 & 12.561 & 11.891 & 11.891 \\
\hline \multicolumn{7}{|c|}{ Males } \\
\hline RD-DD & 0.014 & 0.015 & 0.007 & 0.009 & -0.061 & -0.063 \\
\hline S.E. & 0.011 & 0.010 & 0.008 & 0.007 & 0.045 & 0.045 \\
\hline$N$ & 17,128 & 17,128 & 17,113 & 17,113 & 9,156 & 9,156 \\
\hline$R^{2}$ & 0.032 & 0.108 & 0.031 & 0.110 & 0.031 & 0.038 \\
\hline $\bar{y}$ & 12.701 & 12.701 & 12.727 & 12.727 & 12.231 & 12.231 \\
\hline Controls & & $\checkmark$ & & $\checkmark$ & & $\checkmark$ \\
\hline
\end{tabular}

The table reports the impact of the reform on students' annual expected earnings, by field and field/level, and actual earnings at age 30. All earning variables are logarithmic. We present the RD-DD estimates where we augment the regression with students born in October-March in the neighboring non-reform years 1982-1983, 1984-1985, 1985-1986, 1986-1987, and 1987-1988. The discontinuity in outcomes is estimated with a local linear regression with separate trends on each side of the cutoff, using a 3-month bandwidth on each side of the cutoff and a triangular kernel. The pairwise difference across columns is the inclusion of control variables.

In the two first columns of Table 7, annual expected earnings are based on gender and field

\footnotetext{
${ }^{32}$ For completeness, we estimate the effect on individuals' employment status at age 27 . Our estimates suggest no impact of the reform on employment status. In the cohort born in 1983, 92.0 percent were employed at age 27 compared with 92.7 percent for the cohort born in 1984. Regression results are available upon request.
} 
of tertiary education studies. Our regression result suggest a very modest positive impact of academic field and gender on the log of expected earnings, E[Earnings $]_{f}$, column 2. The estimated effect corresponds to an approximate increase of 30.6 USD in annual expected earnings. However, the effect disappears when stratifying earnings by level of tertiary educational attainment, E[Earnings $]_{f l}$, in columns 3 and 4 . In columns 5 and 6 , we estimate the impact of the reform on actual individual earnings at age 30, Earnings 30 , exploiting a subset of the sample. We restrict the analysis to contain the reform cutoff and one pre- and post- control cutoff year, which reduces the sample size. In sum, we find no economically significant impact of the reform on neither (the log of) annual expected earnings nor actual earnings at age 3033

\subsection{Possible mediator}

One possible explanation for the positive impact on enrollment in tertiary education is that students' upper secondary GPAs may have increased after the reform. Recall that, part of the rationale for the reform was that students in the Social Science program were too limited in their freedom to choose courses based on personal preferences and that they experienced mathematics as particularly demanding, resulting in a high fail rate in the Mathematics $\mathrm{C}$ course. Prior to the reform, more than a fifth of all social science students failed the course, and we take this as evidence of the course being particularly difficult for this group of students. A failing grade naturally decreases a student's grade point average (GPA) when applying for tertiary education. Hence, after the reform, students had the option to replace Mathematics $\mathrm{C}$ with a course for which they expected to receive a higher grade and thus boost their overall GPA. In general, more overall flexibility in course selection may induce students to act strategically by taking relatively simpler courses or choose courses based on innate ability and preferences. Either of these behavioral responses can be expected to increase students' overall GPA and make them more competitive in the tertiary education application process.

\footnotetext{
${ }^{33}$ Earnings are measured in 2015 values and the exchange rate per December 31, 2015.
} 
Table 8: Grade point average

\begin{tabular}{|c|c|c|}
\hline & $\begin{array}{c}\text { GPA } \\
(1) \\
\end{array}$ & $\begin{array}{c}\text { GPA } \\
(2) \\
\end{array}$ \\
\hline \multicolumn{3}{|c|}{ All } \\
\hline RD-DD & $0.381^{* * *}$ & $0.366^{* * *}$ \\
\hline Standard Error & 0.099 & 0.079 \\
\hline Observations & 45,914 & 45,914 \\
\hline$R^{2}$ & 0.038 & 0.250 \\
\hline Pre-reform mean & 14.265 & 14.265 \\
\hline \multicolumn{3}{|c|}{$\begin{array}{l}\text { Females } \\
\end{array}$} \\
\hline RD-DD & $0.356^{* * *}$ & $0.391^{* * *}$ \\
\hline Standard Error & 0.103 & 0.086 \\
\hline Observations & 29,611 & 29,611 \\
\hline$R^{2}$ & 0.037 & 0.238 \\
\hline Pre-reform mean & 14.630 & 14.630 \\
\hline \multicolumn{3}{|c|}{\begin{tabular}{|l} 
Males \\
\end{tabular}} \\
\hline RD-DD & $0.334^{* *}$ & $0.322^{* *}$ \\
\hline Standard Error & 0.151 & 0.132 \\
\hline Observations & 16,303 & 16,303 \\
\hline$R^{2}$ & 0.059 & 0.221 \\
\hline Pre-reform mean & 13.555 & 13.555 \\
\hline
\end{tabular}

The table reports the impact of the reform on students' grade point average. We present the RD-DD estimates where we augment the regression with students born in October-March in the neighboring non-reform years 1982-1983, 1984-1985, 1985-1986, 1986-1987, and 1987-1988. The discontinuity in outcomes is estimated with a local linear regression with separate trends on each side of the cutoff, using a 3 -month bandwidth on each side of the cutoff and a triangular kernel. The pairwise difference across columns is the inclusion of control variables.

We estimate the impact of the reform on individual students' final upper secondary school GPA. This is a continuous variable ranging from 0 to 20. During the period of interest, Swedish upper secondary school students received the grade fail, pass, pass with distinction or pass with special distinction. If students received a passing grade in all courses, they obtain a final upper secondary GPA of 10. The regression results presented in Table 8 do confirm a postreform increase in average GPA ${ }^{34}$ From the RD-DD estimation, we find an approximate 0.4 increase in average GPA. In terms of magnitude, this is approximately equivalent to replacing a grade of pass in Mathematics $\mathrm{C}$ with a grade of pass with special distinction in another

\footnotetext{
${ }^{34}$ One concern is the possibility that GPAs trended upwards due to factors unrelated to the reform, e.g., grade inflation. While we cannot assess such inflation concerns by looking at upper secondary school GPAs, we plot the distribution of lower secondary GPAs in Figure A5 for the 1982-1988 cohorts. We find no striking evidence of grade inflation and conclude that the increase in upper secondary school GPA was mainly driven by substitution of courses.
} 
course. The point estimate is similar for males and females but females come from a slightly higher baseline, resulting in a marginally lower relative increase in GPA.

The estimated increase in students' average GPA implies that students are more competitive in the admission processes for tertiary education. This result provides tentative evidence of students' GPA as a mediator of the positive impact of the reform on tertiary education enrollment in Table 6. If students in the Social Science program became more competitive in the admission process after the reform, a natural question to ask is whether these students out-competed applicants from other upper secondary programs. We estimate the impact of the reform on tertiary education outcomes for students in vocational programs and the Natural Science program and present the regressions in Table A6 35 The results suggest that the reform had no impact on any educational outcomes for the natural science students, while there was a slight decrease in the probability of choosing a $M a-C$ field for students in a vocational program. However, this effect is unlikely to be driven by social science students out-competing students from vocational programs since we find no impact of the reform on their probability of entering fields in tertiary education that require the pivotal mathematics course in Table 6 . Hence, our results show no indication that students in the Social Science program out-competed students in other programs with higher grades and thereby securing tertiary education at the expense of other contemporary students. Instead, the most likely explanation is that the treated social science students enrolled in non-capacity constrained tertiary education fields.

\subsubsection{Teachers mathematics response}

As we have shown, the reform resulted in a significant drop in mathematics attainment among students in the Social Science program. One may wonder if teachers in mathematics responded to this decrease by altering their subjective grade assessment in mathematics courses. A priori, it is not straightforward in what direction the teachers' response would shift. Teachers could have responded to the reform by becoming more lenient in the grading of students in the mathematics course (B) preceding the pivotal course (C) to encourage students to take another mathematics course.Alternatively, they may have increased their expectations of student performance, thus increasing the difficulty of their teaching or stringency in grade

\footnotetext{
${ }^{35}$ Note that we cannot estimate the effect on students entering the Technology program after the reform due to the absence of a proper control group.
} 
setting since they knew that students were less likely to take any more mathematics courses after the reform than before. Note that in Sweden, grading criteria are regulated at the national level, and students also take nationally standardized tests in mathematics 36 While we cannot observe the teachers' attitudes and subjective grading within the classroom, in Table 9 we provide descriptive statistics of the shares of students assigned each of the four available grades before and after the reform.

\begin{tabular}{|c|c|c|c|c|c|c|c|}
\hline & \multicolumn{3}{|c|}{ Before reform cohort 1983} & \multicolumn{3}{|c|}{ After reform cohort 1984} & \multirow[b]{2}{*}{ Diff in means } \\
\hline & Mean (1983) & Std. Dev & Obs. & Mean (1984) & Std. Dev & Obs. & \\
\hline \multicolumn{8}{|l|}{ Mathematics B grade } \\
\hline \multicolumn{8}{|l|}{ Social Science } \\
\hline Fail & 0.14 & 0.35 & 18472 & 0.17 & 0.37 & 18500 & $0.0236^{* * *}$ \\
\hline Pass & 0.55 & 0.50 & 18472 & 0.50 & 0.50 & 18500 & $-0.0512^{* * *}$ \\
\hline Pass with distinction & 0.24 & 0.42 & 18472 & 0.24 & 0.43 & 18500 & 0.0044 \\
\hline Pass with special distinction & 0.07 & 0.25 & 18472 & 0.09 & 0.29 & 18500 & $0.0232^{* * *}$ \\
\hline \multicolumn{8}{|l|}{ Natural Science } \\
\hline Fail & 0.01 & 0.10 & 12981 & 0.01 & 0.08 & 11869 & $-0.0032^{* *}$ \\
\hline Pass & 0.30 & 0.46 & 12981 & 0.22 & 0.41 & 11869 & $-0.0850^{* * *}$ \\
\hline Pass with distinction & 0.37 & 0.48 & 12981 & 0.39 & 0.49 & 11869 & $0.0266^{* * *}$ \\
\hline Pass with special distinction & 0.32 & 0.47 & 12981 & 0.38 & 0.49 & 11869 & $0.0617^{* * *}$ \\
\hline \multicolumn{8}{|l|}{ Vocational Programs } \\
\hline Fail & 0.24 & 0.43 & 9780 & 0.24 & 0.43 & 10864 & 0.0013 \\
\hline Pass & 0.52 & 0.50 & 9780 & 0.51 & 0.50 & 10864 & -0.0101 \\
\hline Pass with distinction & 0.19 & 0.39 & 9780 & 0.18 & 0.39 & 10864 & -0.0030 \\
\hline Pass with special distinction & 0.05 & 0.21 & 9780 & 0.06 & 0.23 & 10864 & $0.0117^{* * *}$ \\
\hline \multicolumn{8}{|l|}{ Technology Program (After) } \\
\hline Fail & & & & 0.06 & 0.23 & 5309 & \\
\hline Pass & & & & 0.54 & 0.50 & 5309 & \\
\hline Pass with distinction & & & & 0.28 & 0.45 & 5309 & \\
\hline Pass with special distinction & & & & 0.12 & 0.33 & 5309 & \\
\hline
\end{tabular}

Table 9: Mathematics B grades for social science students

From Table 9 it is clear that the fraction of students who obtained the highest grade increased for all programs. One reason for this may be that the Swedish National Agency for Education issued national guidelines for the highest grade at the same time as GY2000 was implemented (Ds 2008:13). Though, this applies equally to all programs which can be seen in Table 9 (although the magnitudes differ). One special feature of the grade pattern for the Social Science program is that the share of students receiving a failing grade significantly increased after the reform. This can be due to several reasons, one being that teachers may have increased their expectations regarding what should be required from a mathematics student in the Social Science program, knowing that the students had a lower probability of taking

\footnotetext{
${ }^{36}$ We do not have access to data on the test scores. As a rule, the scores for the national tests should support the teachers grading of the students, although a small discrepancy between the test scores and final grades is allowed.
} 
another mathematics course (Mathematics C) after the reform.

\subsection{Treatment Heterogeneity}

In this section we examine two dimensions of treatment heterogeneity: parents' socio-economic status (SES) and students' final GPA from lower secondary school.

\subsubsection{Socio-Economic Status}

Existing research finds a strong and robust association between an individuals' educational outcomes and parents' SES (Björklund and Salvanes, 2011). According to Björklund and Salvanes (2011) parents' location in the SES distribution may affect a child's educational outcomes through differences in parents' choice of investments in child education and the quantity and quality of information provided to the child about educational prospects. Educational policies and school reforms have the capacity to reduce or reinforce the association between family background and students' educational outcomes and earnings. To investigate the distributional impact of a more flexible curriculum on students educational outcomes along the dimension of SES, we construct an index based on a principal component analysis 37 The results presented in Figure 2 suggest some treatment heterogeneity on outcomes based on parents' SES ${ }^{38}$ There are no clear patterns in the heterogeneity, the exception being a negative trend with regard to the probability of enrolling in a university program with Mathematics C as an entry requirement. Somewhat surprisingly, our estimates show a negative impact in the higher part of the SES distribution while the impact is positive in the lower quartiles. In the first quartile, the magnitude of the effect is sizeable. We estimate a 2.4 percentage point increase in the probability of choosing a post-secondary academic field that requires Mathematics $\mathrm{C}$, which is equivalent to an increase of approximately 19 percent given the low baseline. The lowest SES quartile also drives the increase in the probability of pursuing any tertiary education and the probability of earning a degree. Within the lowest quartile, the reform led to an increase in the former outcome of 5.3 percentage points, or 9.6 percent relative to baseline. For the latter outcome, the increase amounts to 18 percent. The heterogeneous impact of the reform in the

\footnotetext{
${ }^{37}$ See Appendix Table A7 for details on the construction of the index.

${ }^{38}$ Corresponding regression results are presented in Appendix Table A8.
} 
other quartiles is less clear and no pattern emerges. Importantly, we conclude that low SES students did not fare worse after the reform. Instead, these students are found to benefit the most from the flexibility induced by the reform.

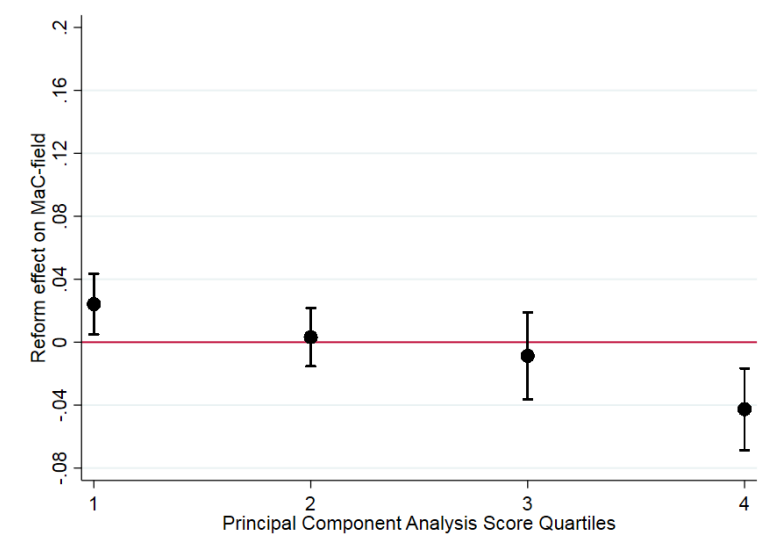

(a) MaC-field

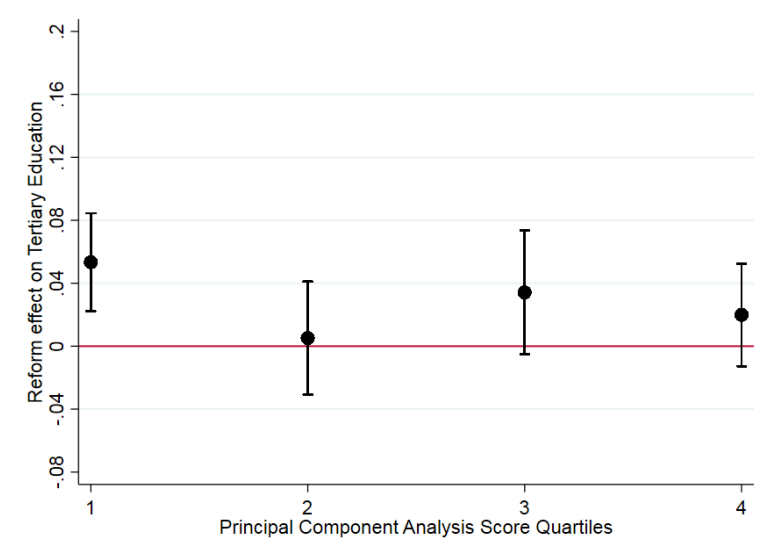

(c) Any Tertiary Education

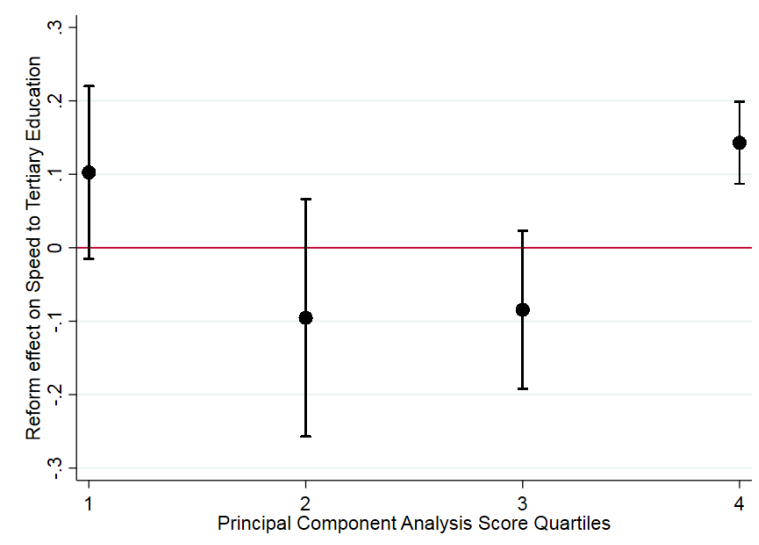

(b) Speed to Tertiary Education

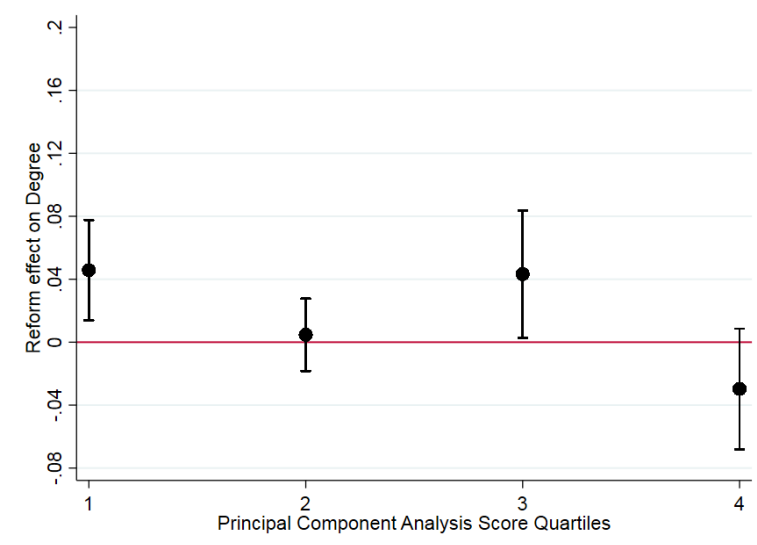

(d) Degree

The figure show the reform coefficient per quartiles from the baseline RD-DD specification with a 3 month bandwidth. The upper and lower bound is calculated at the 90 percent level of significance. The quartiles are based on the distribution of a SES-index constructed based on principal components.

Figure 2: Educational Outcomes by Socio-Economic Status Quartile

\subsubsection{Lower Secondary GPA}

We examine how the impact of the curriculum reform varies with the quartile of students' final GPA from lower secondary school. Since grades from lower secondary school are unaffected by the reform, we are able to condition on students' location in the grade distribution to investigate whether the reform affected students in different parts of the grade distribution differently. Our results presented in Figure 3 show that the effect on enrollment in tertiary 
education and earning a degree is mainly driven by increases in the middle of the grade distribution, more precisely the third quartile. This is not surprising. It is likely that neither the least able nor the most able students had much to gain from a more flexible curriculum. The least able students might have had a very restricted set of choices and hence, even when more curriculum flexibility was introduced, the scope for individual/behavioral responses to the reform may have been limited. On the other extreme, the most able students may not have experienced that a strict course curriculum restricted their choice sets. Given their high ability to cope with a wide range of subjects, they may not have felt restrained by the "old," rigid course curriculum since the mandated courses were not a discouraging factor. Therefore, the scope for behavioral responses to an increase in course-taking flexibility is expected to be largest in the middle of the grade distribution.

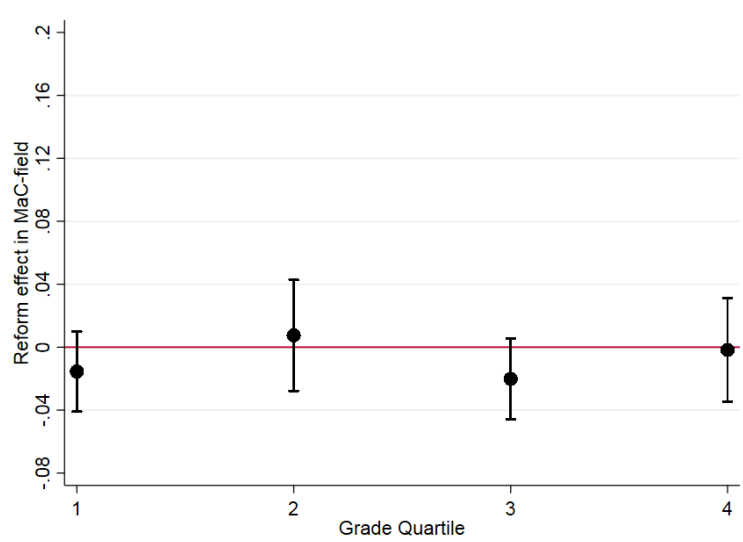

(a) MaC-field

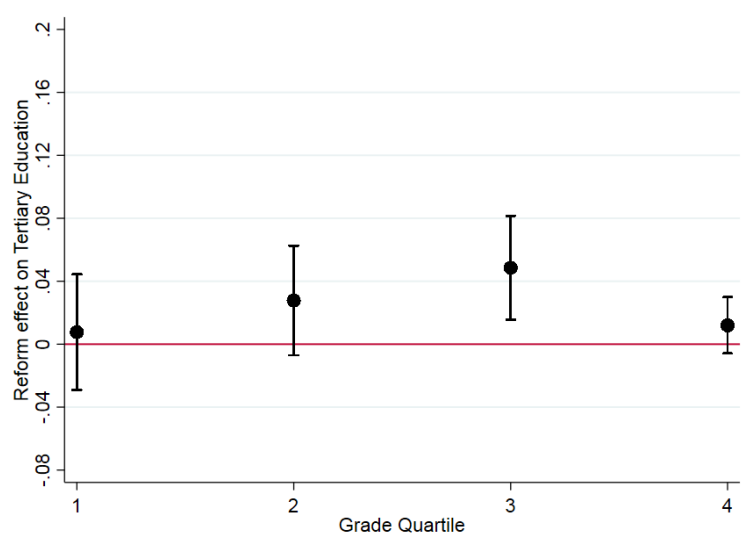

(c) Any Tertiary Education

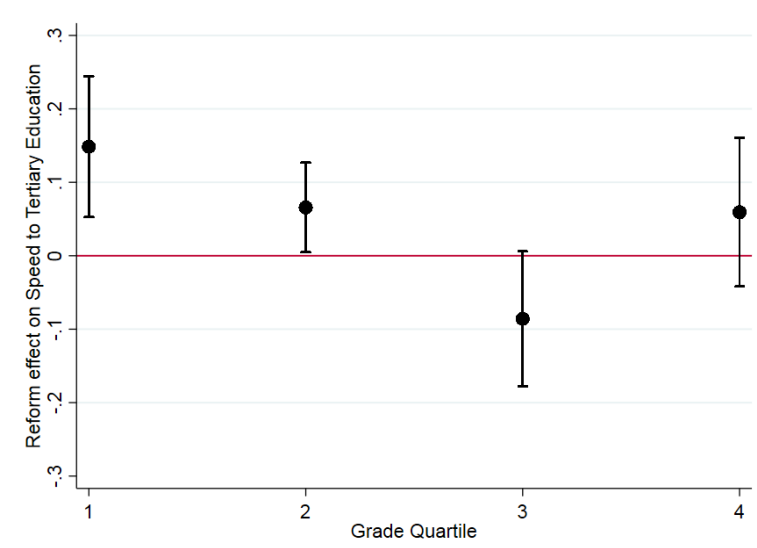

(b) Speed to Tertiary Education

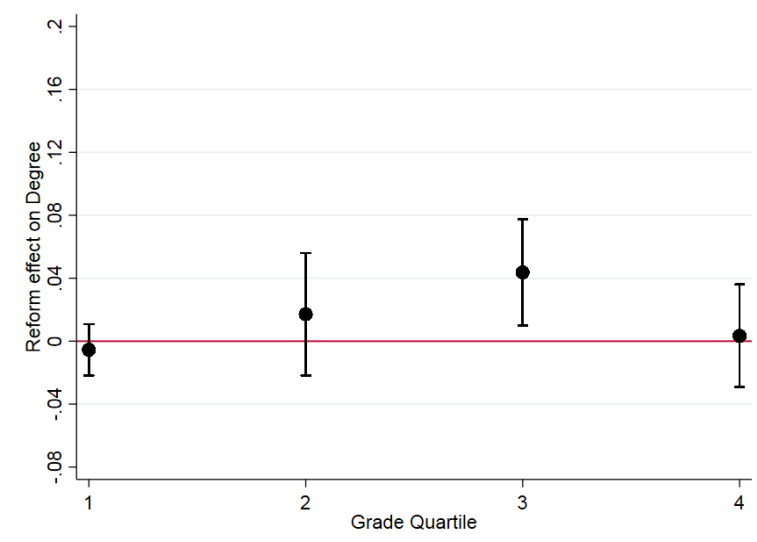

(d) Degree

The figure show the reform coefficient per quartiles from the baseline RD-DD specification with a 3 month bandwidth. The upper and lower bound is calculated at the 90 percent level of significance. The quartiles are based on the distribution of lower secondary school grades for every cohort.

Figure 3: Educational Outcomes by Grade Quartile 


\section{Robustness Checks}

In this section, we provide several robustness checks to test the sensitivity of our results.

\section{Alternative bandwidths}

The choice of bandwidth is important in an RD framework. Due to the discontinuous nature of the running variable, data-driven processes to find the optimal bandwidth cannot be applied in a meaningful way. The bandwidth is selected to balance precision and bias (Calonico et al. 2014). In Figure 4, we test the sensitivity of the point estimates presented in Table 6 to different choices of bandwidth, ranging from 1 to 6 months on each side of the cutoff, i.e., January 1984. 


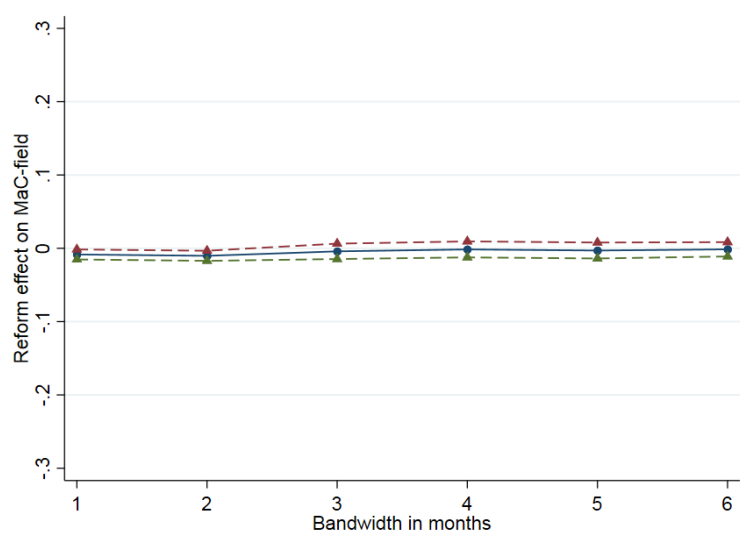

(a) MaC-field

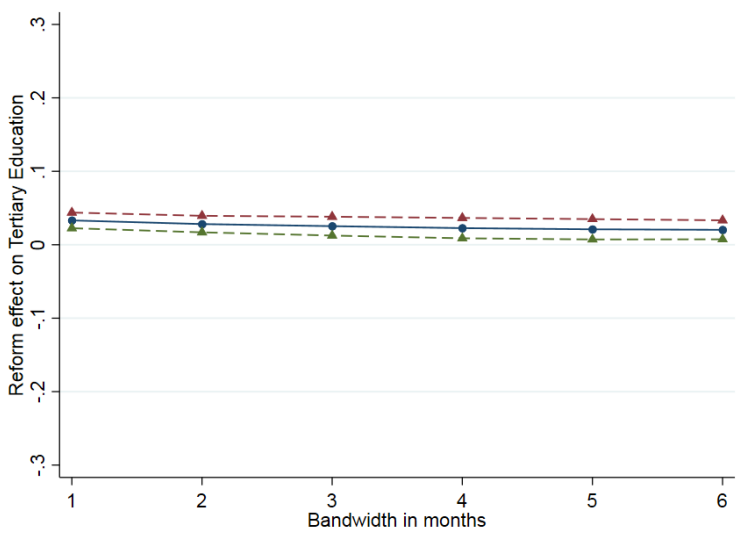

(c) Any Tertiary Education

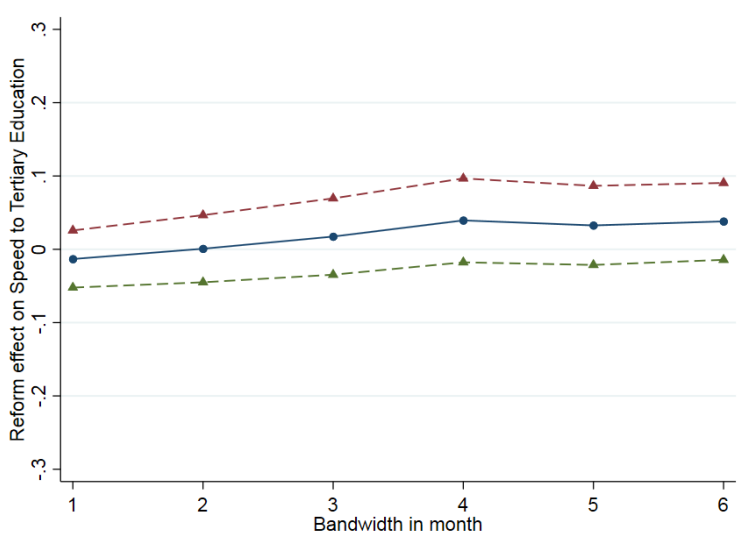

(b) Speed to Tertiary Education

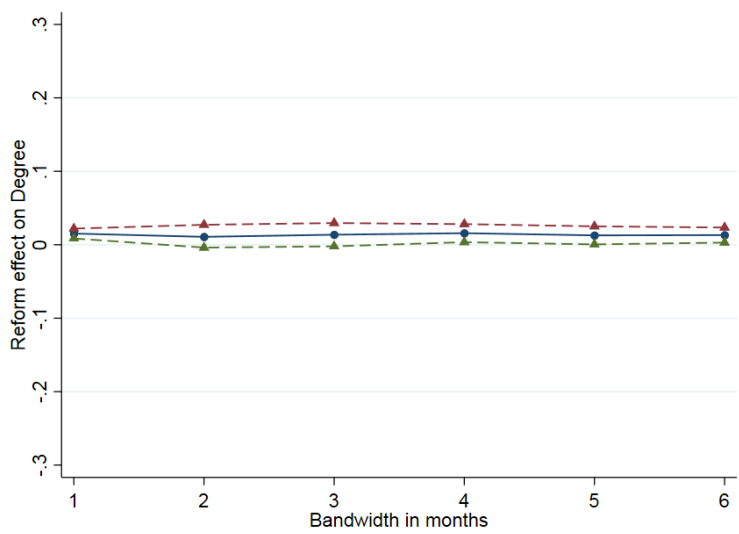

(d) Degree

The figure shows the reform coefficient from the baseline RD-DD specification, including controls, with months included on each side of the threshold along the x-axis. The upper and lower bounds are calculated at the 95 percent level of significance.

Figure 4: Point estimates from alternative bandwidths

Figure 4 shows that the exact point estimate is fairly insensitive to bandwidth. Recall that we have used 3 months on each side of the threshold throughout the main analysis. Neither the probability of having one's highest education in a math-intensive field or the speed of entering tertiary education is statistically distinguishable from zero for any of the different specifications. Regarding the probability of attaining any tertiary education, the magnitude of the coefficient decreases marginally with bandwidth, yet the point estimate from a specification using 1 month is not statistically distinguishable from the 6-month specification. The same pattern holds for the probability of earning a degree from tertiary education. The point estimates are stable and insensitive to the exact choice of bandwidth. 


\subsection{Robustness to other reforms}

The 90s was a decade of many school reforms in Sweden ${ }^{39}$ However, during the time of our study, most of these reforms were already in place. To the best of our knowledge, the only overlapping reform was a change in admission rule to oversubscribed upper secondary schools in a handful of municipalities ${ }^{40}$ In Table 10 we exclude the affected municipalities, Stockholm and Malmö. Since these are two large municipalities, the exclusion leads to lower precision. Overall, the results are qualitatively similar to the main results presented in Table 6.

Table 10: Tertiary educational outcomes - excluding Stockholm and Malmö

\begin{tabular}{|c|c|c|c|c|c|c|c|c|}
\hline & $\begin{array}{c}\text { MaC-field } \\
(1)\end{array}$ & $\begin{array}{c}\text { MaC-field } \\
(2)\end{array}$ & $\begin{array}{c}\text { Speed } \\
(3)\end{array}$ & $\begin{array}{c}\text { Speed } \\
(4)\end{array}$ & $\begin{array}{c}\text { Any TE } \\
(5)\end{array}$ & $\begin{array}{c}\text { Any TE } \\
(6)\end{array}$ & $\begin{array}{c}\text { Degree } \\
(7)\end{array}$ & $\begin{array}{c}\text { Degree } \\
(8)\end{array}$ \\
\hline \multicolumn{9}{|c|}{ All } \\
\hline RD-DD & -0.008 & -0.006 & 0.009 & 0.011 & $0.027 * *$ & $0.027^{* * *}$ & $0.018^{* *}$ & $0.017^{* *}$ \\
\hline Standard Error & 0.007 & 0.007 & 0.031 & 0.029 & 0.011 & 0.008 & 0.009 & 0.008 \\
\hline Observations & 38,994 & 38,994 & 26,232 & 26,232 & 41,497 & 41,497 & 41,497 & 41,497 \\
\hline$R^{2}$ & 0.016 & 0.043 & 0.029 & 0.05 & 0.021 & 0.114 & 0.021 & 0.080 \\
\hline Pre-reform mean & 0.177 & 0.177 & 2.565 & 2.565 & 0.674 & 0.674 & 0.335 & 0.335 \\
\hline \multicolumn{9}{|c|}{ Females } \\
\hline RD-DD & -0.012 & -0.010 & 0.025 & 0.020 & $0.018^{* *}$ & $0.021^{* * *}$ & $0.023^{* *}$ & $0.026^{* *}$ \\
\hline Standard Error & 0.011 & 0.011 & 0.032 & 0.031 & 0.007 & 0.005 & 0.010 & 0.010 \\
\hline Observations & 25,257 & 25,257 & 18,291 & 18,291 & 26,516 & 26,516 & 26,516 & 26,516 \\
\hline$R^{2}$ & 0.017 & 0.038 & 0.035 & 0.050 & 0.025 & 0.093 & 0.026 & 0.059 \\
\hline Pre-reform mean & 0.170 & 0.170 & 2.504 & 2.504 & 0.729 & 0.729 & 0.386 & 0.386 \\
\hline \multicolumn{9}{|c|}{ Males } \\
\hline RD-DD & -0.001 & -0.000 & -0.010 & -0.005 & 0.035 & $0.036^{*}$ & -0.001 & -0.001 \\
\hline Standard Error & 0.010 & 0.009 & 0.076 & 0.075 & 0.025 & 0.020 & 0.016 & 0.014 \\
\hline Observations & 13,737 & 13,737 & 7,941 & 7,941 & 14,981 & 14,981 & 14,981 & 14,981 \\
\hline$R^{2}$ & 0.032 & 0.068 & 0.047 & 0.062 & 0.036 & 0.111 & 0.028 & 0.064 \\
\hline Pre-reform mean & 0.189 & 0.189 & 2.712 & 2.712 & 0.574 & 0.574 & 0.243 & 0.243 \\
\hline Controls & & $\checkmark$ & & $\checkmark$ & & $\checkmark$ & & $\checkmark$ \\
\hline
\end{tabular}

The table reports the impact of the reform on tertiary education outcomes. We present the RD-DD estimates where we augment the regression with students born in October-March in the neighboring non-reform years 1982-1983, 1984-1985, 1985-1986, 1986-1987, and 1987-1988. The discontinuity in outcomes is estimated with a local linear regression with separate trends on each side of the cutoff, using a 3-month bandwidth on each side of the cutoff and a triangular kernel. The pairwise difference across columns is the inclusion of control variables.

\footnotetext{
${ }^{39}$ See Holmlund et al. (2014) for a thourough analysis of the Swedish school reforms in 1990s.

${ }^{40}$ Söderström and Uusitalo (2010) studies the impact of this reform in the municipality including the capital of Sweden, Stockholm, and find that the new admission rule increased sorting in inner city schools. Molin (2019) expands the analysis and finds that the admission reform changed the socio-demographic composition of students only in two municipalities: Malmö and Stockholm.
} 


\section{Conclusion}

A rigid and non-flexible curriculum regime provides a tool for policy makers to ensure a desirable level of human capital accumulation and keep the level of acquired knowledge fixed among students. However, it also denies individuals the freedom to take courses they are interested in and that are in line with their personal aspirations. Ultimately, ignoring individual heterogeneity may even cause less able students to shy away from further education.

Our paper contributes to understanding this curriculum trade-off by exploring an upper secondary school reform in Sweden implemented in year 2000. A main feature of the reform involved an increase in the share of elective course work. More specifically, the reform reduced the mandatory mathematics course load in the most popular upper secondary school program, the Social Science program.

Using detailed register data, we provide evidence that students' course-taking behavior changed after the reform. In particular, mathematics attainment experienced a sharp and robust decrease while enrollment in elective courses in non-STEM fields increased dramatically. The decrease in mathematics attainment was not compensated by an increase in STEM-field related coursework.

We estimate a positive causal impact of the reform on students' probability of ever enrolling in tertiary education, an increase of almost 4 percent. The effect was larger for males than for females. The positive impact on social science students' enrollment in tertiary education translates into an increase in the probability of students exiting tertiary education with a degree. Estimating the effect by gender shows that the positive impact on the probability of earning a degree was driven by a large and positive impact for females. While the curriculum reform increased educational attainment among students in the Social Science program, we find that it did not do so at the expense of a corresponding decrease in contemporary cohorts in the Natural Science or vocational programs. The most likely explanation for this is that the treated social science students enrolled in non-capacity constrained tertiary education fields.

We provide evidence that the decreased required course load in mathematics and increased GPAs can explain part of the increase in transmission from upper secondary school to tertiary 
education. The increase in GPA is in line with results found in Yu and Mocan (2018), the paper most closely related to our work, explicitly investigating curriculum flexibility. They, too, find a positive impact on GPAs when students in China were given more course choice flexibility.

Interestingly, no effect of the reform was found on the probability of having the highest degree in a relatively mathematics-intensive field or on the speed of students entering tertiary education after graduating from upper secondary school. We interpret these null effects as evidence that students, on average, made informed choices regarding their own expected returns from mathematics attainment after the reform.

Our heterogeneity analysis reveals that relatively disadvantaged students (measured along a socio-economic status index) were not negatively affected by the curriculum reform. Rather, students in the lowest SES quartile seem to have benefitted the most from the more flexible curriculum. We further show that final GPA from lower secondary school is an important source of treatment heterogeneity. In particular, the positive impact of the reform on tertiary education was primary driven by students in the upper middle of the grade distribution.

Our results are informative for policy makers speculating about the optimal level of flexibility. Increasing flexibility brings no evidence of negative effects, which suggest that the reform was, at least, an improvement. In addition, the positive results on tertiary education with a particular emphasis on relatively more disadvantaged students suggest that increased course choice flexibility led to more investments in human capital and possibly a dismantling of the socio-demographic gradient in educational attainment. 


\section{References}

Altonji, J. G. (1995). The effects of high school curriculum on education and labor market outcomes. The Journal of Human Resources 30(3), 409-438.

Bertrand, M., M. Mogstad, and J. Mountjoy (2019). Improving educational pathways to social mobility: Evidence from Norway's "Reform 94". NBER Working Paper Series (Working Paper 25679).

Bhuller, M., M. Mogstad, and K. G. Salvanes (2017). Life-cycle earnings, education premiums, and internal rates of return. Journal of Labor Economics 35(4), 993-1030.

Björklund, A. and K. G. Salvanes (2011). Chapter 3 - education and family background: Mechanisms and policies. Handbook of the Economics of Education 3, 201-247.

Black, S. E., P. J. Devereux, and K. G. Salvanes (2011). Too young to leave the nest? the effects of school starting age. The Review of Economics and Statistics 93(2), 455-467.

Calonico, S., M. D. Cattaneo, and R. Titiunik (2014). Robust nonparametric confidence intervals for regression-discontinuity designs. Econometrica 82(6), 2295-2326.

Carneiro, P., K. V. Løken, and K. G. Salvanes (2015). A flying start? maternity leave benefits and long-run outcomes of children. Journal of Political Economy 123(2), 365-412.

Cheng, M.-Y., J. Fan, and J. S. Marron (1997). On automatic boundary corrections. The Annals of Statistics 25(4), 1691-1708.

Fredriksson, P. and B. Öckert (2014). Life-cycle effects of age at school start. The Economic Journal 124(579), 977-1004.

Gelman, A. and G. Imbens (2018). Why high-order polynomials should not be used in regression discontinuity designs. Journal of Business \& Economic Statistics 0(0), 1-10.

Goodman, J. (2017). The labor of division: Returns to compulsory high school math coursework. NBER Working Paper Series (Working Paper 23063).

Görlitz, K. and C. Gravert (2018). The effects of a high school curriculum reform on university enrollment and the choice of college major. Education Economics 26(3), 321-336. 
Hanushek, E. A. and D. D. Kimko (2000). Schooling, labor-force quality, and the growth of nations. American Economic Review 90, 1184-1208.

Holmlund, B., Q. Liu, and O. Nordstrom Skans (2007). Mind the gap? Estimating the effects of postponing higher education. Oxford Economic Papers 60(4), 683-710.

Holmlund, H., J. Häggblom, E. Lindahl, S. Martinson, A. Sjögren, U. Vikman, and B. Öckert (2014). Decentralisering, skolval och fristående skolor: resultat och likvärdighet i svensk skola.

Joensen, J. S. and H. S. Nielsen (2016). Mathematics and gender: Heterogeneity in causes and consequences. Economic Journal 126(593), 1129-1163.

Kirkeboen, L. J., E. Leuven, and M. Mogstad (2016). Field of study, earnings, and selfselection. The Quarterly Journal of Economics 131(3), 1057-1111.

Lee, D. S. and D. Card (2008). Regression discontinuity inference with specification error. Journal of Econometrics 142, 655-674.

Lee, D. S. and T. Lemieux (2010). Regression discontinuity designs in economics. Journal of Economic Literature 48(2), 281-355.

Levine, P. B. and D. J. Zimmerman (1995). The benefit of additional high-school math and science classes for young men and the benefit of additional high-school. Journal of Business E Economic Statistics 13(2), 137-149.

Malamud, O. and C. Pop-Eleches (2010). General education versus vocational training: Evidence from an economy in transition. Review of Economics and Statistics 92(1), 43-60.

Malamud, O. and C. Pop-Eleches (2011). School tracking and access to higher education among disadvantaged groups. Journal of Public Economics 95(11-12), 1538-1549.

McEwan, P. J. and J. S. Shapiro (2008). The benefits of delayed primary school enrollment. Journal of Human Resources 43(1), 1-29.

Molin, E. (2019). School choice and student sorting - the impact of changing admission criteria. Unpublished results. 
Ning, J. (2014). Do stricter high school math requirements raise college STEM attainment? Unpublished results.

Noddings, N. (2011). Schooling for democracy. Democracy \& Education 19(1).

OECD (2018). Education at a Glance 2018: OECD Indicators. OECD Publishing, Paris., http://dx.doi.org/10.1787/eag-2018-en.

Rose, H. and J. R. Betts (2004). The effect of high school courses on earnings. Review of Economics and Statistics 86(2), 497-513.

Söderström, M. and R. Uusitalo (2010). School choice and segregation: Evidence from an admission reform. Scandinavian Journal of Economics 112(1), 55-76.

Sosa, A. (2016). Impact of mathematics course taking during high school on earnings : Evidence from shocks to teachers' supply. Unpublished results.

Yu, H. and N. Mocan (2018). The impact of high school curriculum on confidence, academic success, and mental and physical well-being of university students. NBER Working Paper Series (Working Paper 24573). 


\section{Online Appendix}

\section{Figures}

Figure A1: Students course-taking behavior, females
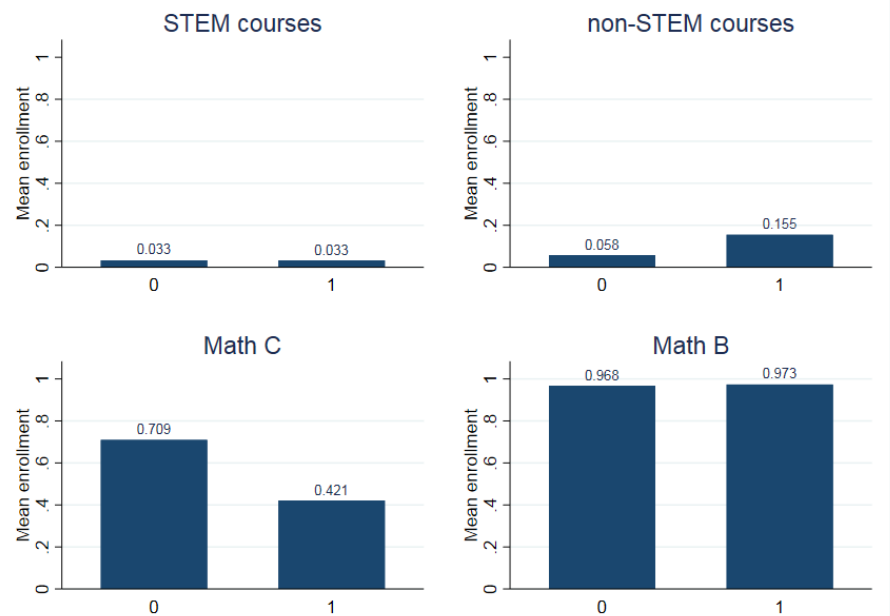

The figure presents enrollment means for female students in the Social Science program in the year before (0) and after (1) the reform. STEM courses consist of courses traditionally offered in the Natural Science program prior to the reform.

Figure A2: Students course-taking behavior, males
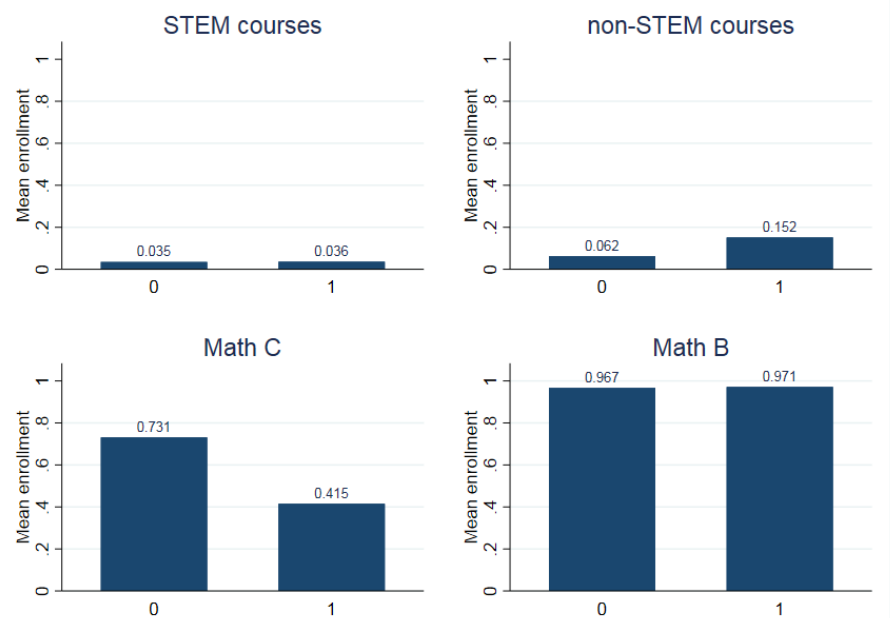

The figure presents enrollment means for male students in the Social Science program in the year before (0) and after (1) the reform. STEM courses consist of courses traditionally offered in the Natural Science program prior to the reform. 
Figure A3: Histogram, birthdate in months

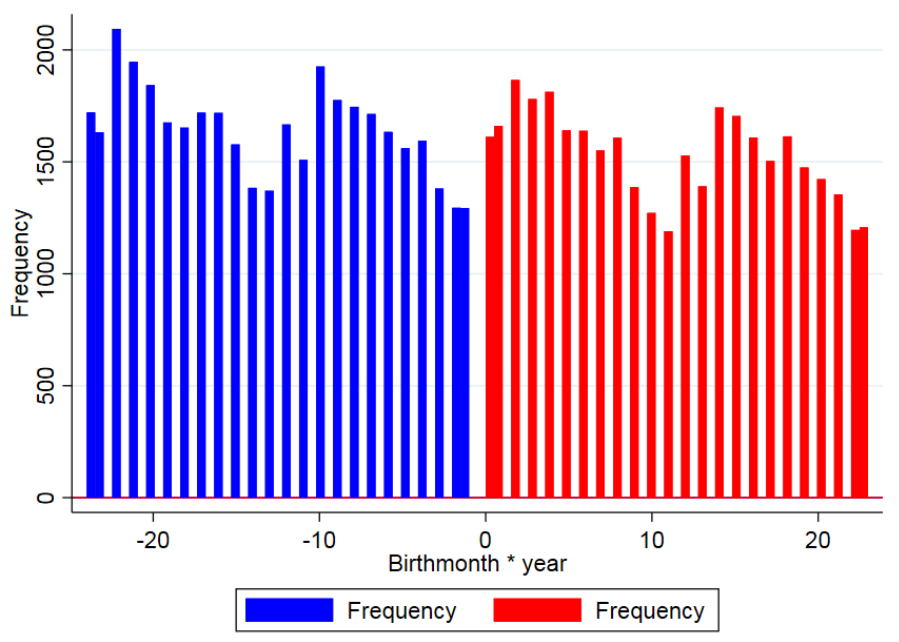

The histogram shows the frequency of observations among social science students born two years before and after the reform. The sample is restricted to individuals born January 1982-December 1985. Zero (0) denotes the cutoff date, born in January 1984, and include individuals who entered upper secondary school after the reform 
Figure A4: RD on control years

(a) MaC-field

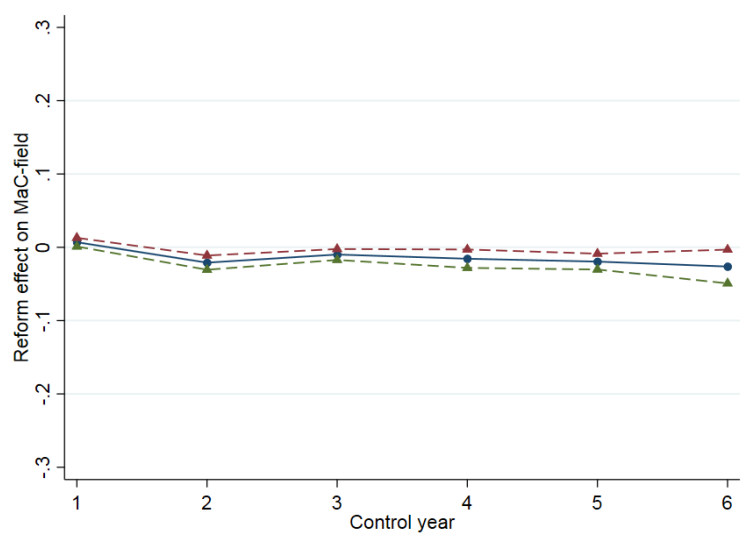

(c) Any Tertiary Education

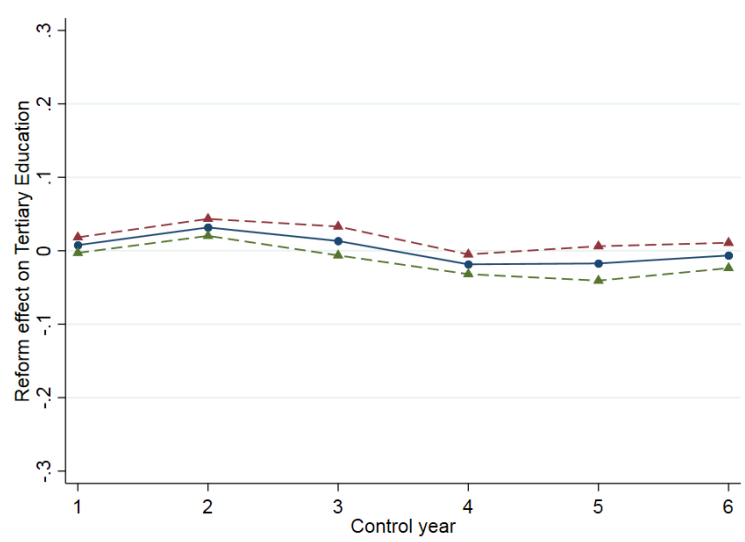

(b) Speed to Tertiary Education

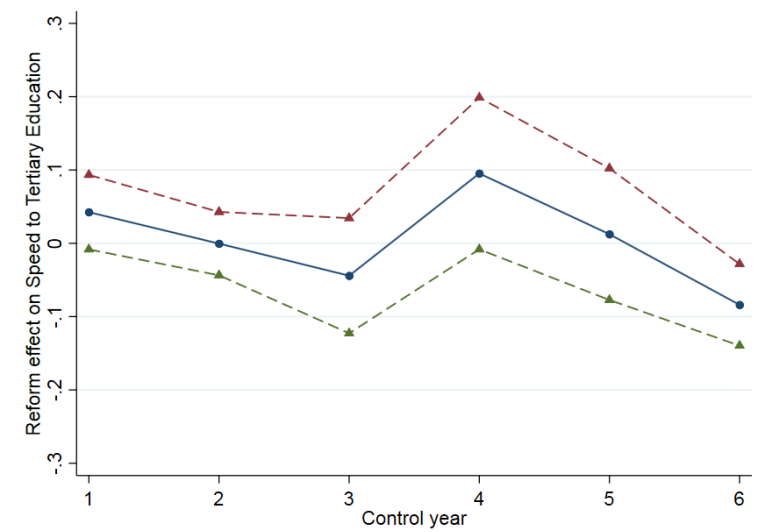

(d) Degree

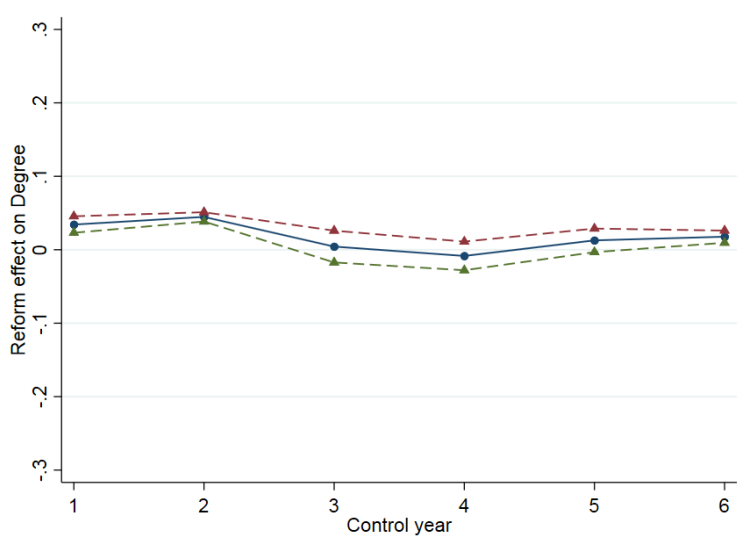

The figure shows the reform coefficient per cutoff from the baseline RD-specification with a 3-month bandwidth. The upper and lower bounds are calculated at the 95 percent level of significance. Year 2 is the actual reform year 1983-1984.

Figure A5: Density plot of lower secondary school GPA

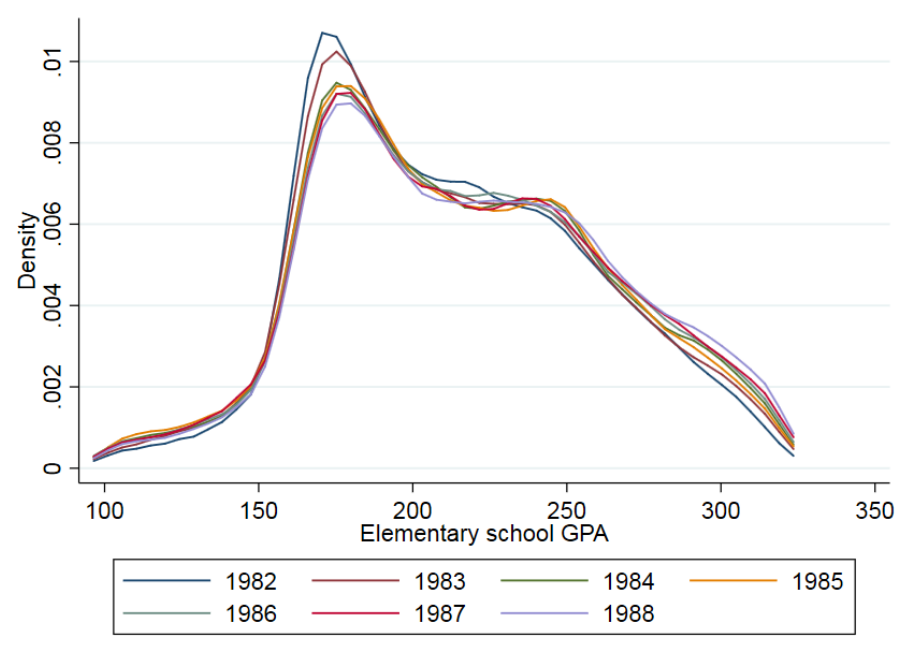

The figure shows the distribution of student lower secondary school GPA for the entire population of students born $1982-1988$ 


\section{Tables}

Table A1: STEM and non-STEM courses

\begin{tabular}{lc}
\hline STEM & Credits \\
\hline Biology A & 100 \\
Biology B & 50 \\
Physics A & 100 \\
Chemistry A & 100 \\
Mathematics D & 100 \\
Environment & 100 \\
\hline non-STEM & Credits \\
\hline Cultural history and contemporary art & 50 \\
Leadership & 100 \\
Media & 100 \\
Multimedia & 100 \\
Humanities & 100 \\
Text communication A & 100 \\
\hline
\end{tabular}

Courses included in STEM and non-STEM categories are selected based on the following premises. First, the courses are included on the Swedish National Agency for Education's list of suitable elective courses for the Social Science program (GY2000:16). Second, the courses are not listed as mandatory in any of the specialization tracks within the Social Science program. Third, the courses must have existed both before and after the implementation of GY2000. The remaining courses are coded as STEM if they are mandatory for students enrolled in any of the specialization tracks within the Natural Science program. The rest of the courses are coded as non-STEM. The included STEM courses basically cover all possible STEM course electives that could be offered in the elective course package. However, the included nonSTEM courses likely cover only a small fraction of all possible non-STEM courses that upper secondary schools may offer their students. 


\begin{tabular}{|c|c|c|c|c|c|c|c|}
\hline & \multicolumn{3}{|c|}{ Before reform cohort 1983} & \multicolumn{3}{|c|}{ After reform cohort 1984} & \multirow[b]{2}{*}{ Diff. in means } \\
\hline & Mean & Std. Error & Obs. & Mean & Std. Error & Obs. & \\
\hline \multicolumn{8}{|l|}{ Social Science } \\
\hline High math ability & 0.46 & 0.50 & 18954 & 0.47 & 0.50 & 18867 & 0.0053 \\
\hline Lower secondary school grade & 225.56 & 40.11 & 18953 & 229.13 & 42.08 & 18867 & $3.5744^{* * *}$ \\
\hline Male & 0.37 & 0.48 & 19098 & 0.35 & 0.48 & 19021 & $-0.0189^{* * *}$ \\
\hline Immigrant & 0.12 & 0.32 & 18023 & 0.13 & 0.33 & 17910 & $0.0070^{*}$ \\
\hline LowEducation $_{p}$ & 0.64 & 0.48 & 17860 & 0.62 & 0.48 & 17766 & $-0.0206^{* * *}$ \\
\hline $\operatorname{LogAvgWage} f$ & 11.00 & 3.81 & 18153 & 11.07 & 3.76 & 18076 & 0.0714 \\
\hline \multicolumn{8}{|l|}{ Natural Science } \\
\hline High math ability & 0.88 & 0.33 & 13075 & 0.89 & 0.31 & 11734 & $0.0156^{* * *}$ \\
\hline Lower secondary school grade & 255.81 & 40.25 & 13071 & 261.75 & 39.41 & 11733 & $5.9472^{* * *}$ \\
\hline Male & 0.58 & 0.49 & 13194 & 0.55 & 0.50 & 11896 & $-0.0328^{* * *}$ \\
\hline Immigrant & 0.12 & 0.32 & 12568 & 0.14 & 0.35 & 11197 & $0.0204^{* * *}$ \\
\hline LowEducation $_{p}$ & 0.48 & 0.50 & 12491 & 0.46 & 0.50 & 11117 & $-0.0211^{* *}$ \\
\hline LogAvgWage & 11.33 & 3.55 & 12655 & 11.36 & 3.57 & 11261 & 0.0323 \\
\hline \multicolumn{8}{|l|}{ Technical Program } \\
\hline High math ability & & & & 0.60 & 0.49 & 5309 & \\
\hline Elementary school grade & & & & 220.05 & 36.91 & 5309 & \\
\hline Male & & & & 0.91 & 0.29 & 5332 & \\
\hline Immigrant & & & & 0.08 & 0.28 & 5094 & \\
\hline LowEducation $_{p}$ & & & & 0.66 & 0.47 & 5075 & \\
\hline $\operatorname{LogAvgWage} e_{f}$ & & & & 11.33 & 3.39 & 5136 & \\
\hline \multicolumn{8}{|l|}{ Vocational } \\
\hline High math ability & 0.19 & 0.39 & 33426 & 0.18 & 0.39 & 34698 & -0.0022 \\
\hline Lower secondary school grade & 182.56 & 42.82 & 33426 & 183.08 & 45.55 & 34698 & 0.5248 \\
\hline Male & 0.54 & 0.50 & 33736 & 0.52 & 0.50 & 34978 & $-0.0183^{* * *}$ \\
\hline Immigrant & 0.10 & 0.30 & 31617 & 0.10 & 0.30 & 32724 & 0.0018 \\
\hline LowEducation $_{p}$ & 0.84 & 0.36 & 31307 & 0.84 & 0.36 & 32392 & -0.0022 \\
\hline $\operatorname{LogAvgWage}_{f}$ & 10.51 & 4.08 & 31960 & 10.57 & 4.06 & 33087 & 0.0515 \\
\hline \multicolumn{8}{|l|}{ All Students } \\
\hline High math ability & 0.40 & 0.49 & 65836 & 0.41 & 0.49 & 70608 & 0.0043 \\
\hline Lower secondary school grade & 209.55 & 50.95 & 65831 & 211.24 & 52.52 & 70607 & $1.6874^{* * *}$ \\
\hline Male & 0.50 & 0.50 & 66433 & 0.51 & 0.50 & 71227 & $0.0080^{* *}$ \\
\hline Immigrant & 0.11 & 0.31 & 62567 & 0.11 & 0.32 & 66925 & 0.0032 \\
\hline LowEducation $_{p}$ & 0.71 & 0.45 & 62007 & 0.71 & 0.46 & 66350 & $-0.0069^{* *}$ \\
\hline $\operatorname{LogAvgWage} e_{f}$ & 10.81 & 3.92 & 63122 & 10.89 & 3.87 & 67560 & $0.0769^{* * *}$ \\
\hline Social Science & 0.29 & 0.45 & 66433 & 0.27 & 0.44 & 71227 & $-0.0204^{* * *}$ \\
\hline Natural Science & 0.20 & 0.40 & 66433 & 0.17 & 0.37 & 71227 & $-0.0316^{* * *}$ \\
\hline Technical & & & & 0.07 & 0.26 & 71227 & \\
\hline VOC & 0.51 & 0.50 & 66433 & 0.49 & 0.50 & 71227 & $-0.0167^{* * *}$ \\
\hline
\end{tabular}

Table A2: Summary statistics of background characteristics 
Table A3: Probability of enrolling in other programs

\begin{tabular}{|c|c|c|c|c|}
\hline Vocational & $\mathrm{RD}$ & $\mathrm{RD}$ & RD-DD & RD-DD \\
\hline & All & & & \\
\hline Reform & $-0.088 * * *$ & $-0.041^{* * *}$ & $-0.048^{* * *}$ & $-0.044^{* * *}$ \\
\hline Standard Error & 0.002 & 0.001 & 0.004 & 0.004 \\
\hline Observations & 30,667 & 30,667 & 184,852 & 184,852 \\
\hline Pre-reform Mean & 0.537 & 0.537 & 0.537 & 0.537 \\
\hline & Girls & & & \\
\hline Reform & $-0.084^{* * *}$ & $-0.040^{* * *}$ & $-0.022^{* * *}$ & $-0.020^{* * *}$ \\
\hline Standard Error & 0.001 & 0.002 & 0.007 & 0.006 \\
\hline Observations & 15,128 & 15,128 & 91,119 & 91,119 \\
\hline Pre-reform Mean & 0.498 & 0.498 & 0.498 & 0.498 \\
\hline & Boys & & & \\
\hline Reform & $-0.093^{* * *}$ & $-0.041 * * *$ & $-0.075^{* * *}$ & $-0.069 * * *$ \\
\hline Standard Error & 0.003 & 0.001 & 0.006 & 0.006 \\
\hline Observations & 15,539 & 15,539 & 93,733 & 93,733 \\
\hline Pre-reform Mean & 0.575 & 0.575 & 0.575 & 0.575 \\
\hline Natural Science & & & & \\
\hline & All & & & \\
\hline Reform & $0.078^{* * *}$ & $0.035^{* * *}$ & $0.053^{* * *}$ & $0.050 * * *$ \\
\hline Standard Error & 0.001 & 0.001 & 0.004 & 0.004 \\
\hline Observations & 30,667 & 30,667 & 184,852 & 184,852 \\
\hline Pre-reform Mean & 0.191 & 0.191 & 0.191 & 0.191 \\
\hline & Girls & & & \\
\hline Reform & $0.044^{* * *}$ & $0.010^{* * *}$ & $0.014^{* * *}$ & $0.013^{* * *}$ \\
\hline Standard Error & 0.003 & 0.002 & 0.004 & 0.004 \\
\hline Observations & 15,128 & 15,128 & 91,119 & 91,119 \\
\hline Pre-reform Mean & 0.151 & 0.151 & 0.151 & 0.151 \\
\hline & Boys & & & \\
\hline Reform & $0.112^{* * *}$ & $0.061^{* * *}$ & $0.093^{* * *}$ & $0.087^{* * *}$ \\
\hline Standard Error & 0.004 & 0.003 & 0.006 & 0.004 \\
\hline Observations & 15,539 & 15,539 & 93,733 & 93,733 \\
\hline Pre-reform Mean & 0.231 & 0.231 & 0.231 & 0.231 \\
\hline Controls & & $\checkmark$ & & $\checkmark$ \\
\hline
\end{tabular}

The table reports the impact of the reform on the probability of enrolling in vocational programs and the Natural Science/Technology programs in upper secondary school. The two first columns show the RD regression results using a 3-month bandwidth on each side of the cutoff and a triangular kernel. The discontinuity in outcomes is estimated with a local linear regression with separate trends on each side of the cutoff. We present the RD-DD estimates where we augment the regression with students born in

October-March in the neighboring non-reform years 1982-1983, 1984-1985, 1985-1986, 1986-1987, and 1987-1988. The pairwise difference across columns is the inclusion of control variables. 
Table A4: Balancing test of pre-treatment characteristics: Social Science

\begin{tabular}{|c|c|c|c|c|c|}
\hline & $\begin{array}{c}\text { HighMath }_{i} \\
(1) \\
\end{array}$ & $\begin{array}{c}\text { Male }_{i} \\
(2) \\
\end{array}$ & $\begin{array}{c}\text { Loweduc }_{p} \\
(3)\end{array}$ & $\begin{array}{c}\text { Foregin }_{p} \\
(4)\end{array}$ & $\begin{array}{c}\operatorname{Ln} \overline{\text { Earnings }}_{f} \\
(5)\end{array}$ \\
\hline \multicolumn{6}{|c|}{ All } \\
\hline $\mathrm{RD}$ & $0.105^{* * *}$ & $-0.024^{* *}$ & 0.000 & $-0.006^{*}$ & $-0.174^{* *}$ \\
\hline Standard Error & 0.011 & 0.009 & 0.014 & 0.003 & 0.045 \\
\hline Observations & 8,442 & 8,442 & 8,442 & 8,442 & 8,442 \\
\hline $\mathrm{RD}-\mathrm{DD}$ & -0.016 & $-0.024^{* * *}$ & -0.003 & -0.005 & -0.048 \\
\hline Standard Error & 0.012 & 0.009 & 0.012 & 0.003 & 0.054 \\
\hline Observations & 48,459 & 48,459 & 48,459 & 48,459 & 48,459 \\
\hline Pre-reform Mean & 0.456 & 0.360 & 0.630 & 0.110 & 11.146 \\
\hline \multicolumn{6}{|c|}{ Females } \\
\hline $\mathrm{RD}$ & $0.094^{* * *}$ & & 0.026 & -0.003 & 0.004 \\
\hline Standard Error & 0.011 & & 0.015 & 0.004 & 0.038 \\
\hline Observations & 5,429 & & 5,429 & 5,429 & 5,429 \\
\hline $\mathrm{RD}-\mathrm{DD}$ & $-0.019^{*}$ & & -0.005 & -0.005 & 0.045 \\
\hline Standard Error & 0.011 & & 0.015 & 0.005 & 0.062 \\
\hline Observations & 30,830 & & 30,830 & 30,830 & 30,830 \\
\hline Pre-reform Mean & 0.481 & & 0.654 & 0.108 & 11.070 \\
\hline \multicolumn{6}{|c|}{ Males } \\
\hline $\mathrm{RD}$ & $0.138^{* * *}$ & & -0.018 & -0.005 & $-0.304^{*}$ \\
\hline Standard Error & 0.012 & & 0.028 & 0.007 & 0.122 \\
\hline Observations & 3,013 & & 3,013 & 3,013 & 3,013 \\
\hline RD-DD & -0.006 & & -0.002 & -0.004 & -0.149 \\
\hline Standard Error & 0.019 & & 0.016 & 0.005 & 0.115 \\
\hline Observations & 17,629 & & 17,629 & 17,629 & 17,629 \\
\hline Pre-reform Mean & 0.412 & & 0.586 & 0.113 & 11.281 \\
\hline
\end{tabular}

The table reports the impact of the reform on pre-determined characteristics. In panel C, we present the RD regression results using a 3-month bandwidth on each side of the cutoff and a triangular kernel. The discontinuity in outcomes is estimated with a local linear regression with separate trends on each side of the cutoff. In panel $\mathrm{D}$, we present the RD-DD estimates where we augment the regression with students born in October-March in the neighboring non-reform years 1982-1983, 1984-1985, 1985-1986, 1986-1987, and 1987-1988. The pairwise difference across columns is the inclusion of control variables. 
Table A5: Balancing test of pre-treatment characteristics: All students

\begin{tabular}{|c|c|c|c|c|c|}
\hline & $\begin{array}{c}\text { HighMath }_{i} \\
\text { (1) }\end{array}$ & $\begin{array}{c}\text { Male }_{i} \\
(2) \\
\end{array}$ & $\begin{array}{c}\text { Loweduc }_{p} \\
(3)\end{array}$ & $\begin{array}{c}\text { Foregin }_{p} \\
(4)\end{array}$ & $\begin{array}{c}\operatorname{Ln}_{\text {Earnings }} \\
(5)\end{array}$ \\
\hline \multicolumn{6}{|c|}{ All } \\
\hline RD-DD & 0.003 & 0.015 & -0.007 & -0.000 & 0.035 \\
\hline Standard Error & 0.007 & 0.006 & 0.004 & 0.003 & 0.051 \\
\hline Observations & 184,852 & 184,852 & 184,852 & 184,852 & 184,852 \\
\hline Pre-reform Mean & 0.379 & 0.504 & 0.723 & 0.105 & 10.870 \\
\hline \multicolumn{6}{|c|}{ Females } \\
\hline RD-DD & -0.007 & & $-0.015^{* *}$ & -0.003 & 0.077 \\
\hline Standard Error & 0.009 & & 0.006 & 0.004 & 0.077 \\
\hline Observations & 91,119 & & 91,119 & 91,119 & 91,119 \\
\hline Pre-reform Mean & 0.401 & & 0.731 & 0.108 & 10.826 \\
\hline \multicolumn{6}{|c|}{ Males } \\
\hline RD-DD & $0.013^{*}$ & & 0.000 & 0.003 & -0.004 \\
\hline Standard Error & 0.007 & & 0.005 & 0.004 & 0.046 \\
\hline Observations & 93,733 & & 93,733 & 93,733 & 93,733 \\
\hline Pre-reform Mean & 0.358 & & 0.715 & 0.102 & 10.914 \\
\hline
\end{tabular}

The table reports the impact of the reform on pre-determined characteristics. In panel $\mathrm{C}$ we present the $\mathrm{RD}$ regression results using a 3-month bandwidth on each side of the cutoff and a triangular kernel. The discontinuity in outcomes is estimated with a local linear regression with separate trends on each side of the cutoff. In panel D We present the RD-DD estimates where we augment the regression with students born in October to March in the neighboring non-reform years 1982-1983, 1984-1985, 1985-1986, 1986-1987, and 1987-1988. The pairwise difference across columns is the inclusion of control variables. 
Table A6: Tertiary education outcomes: Other programs

\begin{tabular}{|c|c|c|c|c|c|c|c|c|}
\hline & $\begin{array}{c}\text { MaC-field } \\
\text { (1) }\end{array}$ & $\begin{array}{c}\text { MaC-field } \\
\text { (2) }\end{array}$ & $\begin{array}{c}\text { Speed } \\
(3)\end{array}$ & $\begin{array}{c}\text { Speed } \\
(4)\end{array}$ & $\begin{array}{c}\text { Any TE } \\
(5)\end{array}$ & $\begin{array}{c}\text { Any TE } \\
(6)\end{array}$ & $\begin{array}{c}\text { Degree } \\
(7)\end{array}$ & $\begin{array}{c}\text { Degree } \\
(8)\end{array}$ \\
\hline \multicolumn{9}{|c|}{ Vocational programs } \\
\hline RD-DD & $-0.019 * * *$ & $-0.019 * * *$ & -0.044 & -0.051 & 0.013 & 0.010 & 0.007 & 0.005 \\
\hline S.E & 0.006 & 0.006 & 0.056 & 0.057 & 0.008 & 0.008 & 0.004 & 0.004 \\
\hline Observations & 61,737 & 61,737 & 20,017 & 20,017 & 93,699 & 93,699 & 93,699 & 93,699 \\
\hline$R^{2}$ & 0.045 & 0.053 & 0.021 & 0.033 & 0.020 & 0.140 & 0.012 & 0.077 \\
\hline Pre-reform $\bar{y}$ & 0.146 & 0.146 & 2.873 & 2.873 & 0.237 & 0.237 & 0.107 & 0.107 \\
\hline \multicolumn{9}{|c|}{ Natural Science } \\
\hline RD-DD & -0.013 & -0.014 & -0.002 & 0.008 & 0.014 & 0.010 & 0.004 & -0.005 \\
\hline S.E & 0.009 & 0.010 & 0.024 & 0.025 & 0.012 & 0.012 & 0.007 & 0.006 \\
\hline Observations & 13,942 & 13,942 & 24,802 & 24,802 & 28,611 & 28,611 & 28,611 & 28,611 \\
\hline$R^{2}$ & 0.034 & 0.042 & 0.027 & 0.040 & 0.019 & 0.064 & 0.018 & 0.057 \\
\hline Pre-reform $\bar{y}$ & 0.202 & 0.202 & 2.275 & 2.275 & 0.863 & 0.863 & 0.475 & 0.475 \\
\hline Controls & & $\checkmark$ & & $\checkmark$ & & $\checkmark$ & & $\checkmark$ \\
\hline
\end{tabular}

The table reports the impact of the reform on tertiary education outcomes. We present the RD-DD estimates where we augment the regression with students born in October-March in the neighboring non-reform years 1982-1983, 1984-1985, 1985-1986, 1986-1987, and 1987-1988. The discontinuity in outcomes is estimated with a local linear regression with separate trends on each side of the cutoff, using a 3-month bandwidth on each side of the cutoff and a triangular kernel. The pairwise difference across columns is the inclusion of control variables. 


\section{Principal Component Analysis}

The SES index is constructed based on a principal component analysis (PCA). The idea is that many socio-demographic characteristics are correlated. For example, having a low educated mother is strongly associated with lower average income. We can exploit the correlation structure to construct one variable, an index, combining the correlated variables. PCA reduces the dimensionality by finding linear combinations of the separate components that explain the most variability. We use the first component since it explains the maximal variation in the original set of predicting variables.

Table A7: Results of the PCA analysis

\begin{tabular}{lc} 
Variable & $\mathrm{PC} 1$ \\
\hline LowEducation $_{f}$ & 0.4328 \\
LowEducation $_{m}$ & 0.4764 \\
Foreign $_{\text {LnAvgEarnings }}$ & 0.3456 \\
LnAvgEarnings $_{f}$ & -0.4736 \\
\hline Percent of variation explained & -0.4920 \\
\hline
\end{tabular}

The principal component has unit length such that:

$P C 1=0.4328^{2}+0.4764^{2}+0.3456^{2}-0.4736^{2}-0.4920^{2}=1$.

Based on the principal component $(\mathrm{PC} 1)$ we create a new variable $(\mathrm{PCA})$ that predicts the individual's $S E S$ index according to a weighted linear combination of the original set of predicting variables:

$P C A_{i}=0.4328$ loweduc $_{f}+0.4764$ loweduc $_{m}+0.3456$ foreign -0.4736 lnavgearn $_{f}-0.4920$ lnavgearn $_{m}$ Finally, we invert the index so that higher values of the index correspond to higher SES and vice versa. 
Table A8: PCA: Tertiary education outcomes by SES quartile

\begin{tabular}{lcccc}
\hline RD-DD & 1st Q(Lowest) & 2nd Q & 3rd Q & 4th Q (Highest) \\
\hline MaC-field & $0.024^{* *}$ & 0.003 & -0.009 & $-0.043^{* * *}$ \\
Standard Error & 0.011 & 0.011 & 0.016 & 0.015 \\
Observations & 11,082 & 11,072 & 11,124 & 10,831 \\
\hline$R^{2}$ & 0.030 & 0.031 & 0.031 & 0.032 \\
Pre-reform mean & 0.124 & 0.151 & 0.194 & 0.241 \\
\hline Speed to Uni & 0.103 & -0.095 & -0.084 & $0.143^{* * *}$ \\
Standard Error & 0.070 & 0.095 & 0.064 & 0.033 \\
Observations & 6,365 & 6,861 & 7,708 & 8,880 \\
\hline$R^{2}$ & 0.061 & 0.056 & 0.053 & 0.041 \\
Pre-reform mean & 2.481 & 2.655 & 2.650 & 2.460 \\
\hline Any TE & $0.053^{* * *}$ & 0.005 & 0.034 & 0.020 \\
Standard Error & 0.018 & 0.021 & 0.023 & 0.019 \\
Observations & 11,725 & 11,721 & 11,867 & 11,679 \\
\hline$R^{2}$ & 0.036 & 0.039 & 0.028 & 0.028 \\
Pre-reform mean & 0.551 & 0.614 & 0.716 & 0.811 \\
\hline Degree & $0.046^{* *}$ & 0.005 & $0.043^{*}$ & -0.030 \\
Standard Error & 0.019 & 0.014 & 0.024 & 0.023 \\
Observations & 11,725 & 11,721 & 11,867 & 11,679 \\
\hline$R^{2}$ & 0.039 & 0.044 & 0.036 & 0.034 \\
Pre-reform mean & 0.257 & 0.303 & 0.365 & 0.403
\end{tabular}

The table reports the impact of the reform on tertiary education outcomes by SES quartile. We present the RD-DD estimates where we augment the regression with students born in October-March in the neighboring non-reform years 1982-1983, 1984-1985, 1985-1986, 1986-1987, and 1987-1988. The discontinuity in outcomes is estimated with a local linear regression with separate trends on each side of the cutoff, using a 3-month bandwidth on each side of the cutoff and a triangular kernel. 
Table A9: Tertiary education outcomes by grade quartile

\begin{tabular}{lcccc}
\hline RD-DD & 1st Q(Lowest) & 2nd Q & 3rd Q & 4th Q (Highest) \\
\hline MaC-field & -0.015 & 0.008 & -0.020 & 0.002 \\
Standard Error & 0.0150 & 0.021 & 0.015 & 0.019 \\
Observations & 11,627 & 10,848 & 11,094 & 10,550 \\
\hline$R^{2}$ & 0.024 & 0.034 & 0.031 & 0.037 \\
Pre-reform mean & 0.105 & 0.185 & 0.218 & 0.225 \\
\hline Speed & $0.149^{* *}$ & 0.066 & -0.086 & 0.059 \\
Standard Error & 0.057 & 0.036 & 0.054 & 0.060 \\
Observations & 4,684 & 6,831 & 8,666 & 9,641 \\
\hline$R^{2}$ & 0.078 & 0.054 & 0.049 & 0.046 \\
Pre-reform mean & 2.926 & 2.70 & 2.528 & 2.262 \\
\hline Any TE & 0.008 & 0.028 & $0.049^{* *}$ & 0.012 \\
Standard Error & 0.022 & 0.021 & 0.020 & 0.011 \\
Observations & 12,336 & 11,548 & 11,842 & 11,277 \\
\hline$R^{2}$ & 0.037 & 0.041 & 0.039 & 0.037 \\
Pre-reform mean & 0.441 & 0.678 & 0.768 & 0.884 \\
\hline Degree & -0.005 & 0.017 & $0.044^{* *}$ & 0.003 \\
Standard Error & 0.010 & 0.023 & 0.020 & 0.019 \\
Observations & 12,336 & 11,548 & 11,842 & 11,277 \\
\hline$R^{2}$ & 0.029 & 0.044 & 0.040 & 0.040 \\
Pre-reform mean & 0.169 & 0.313 & 0.412 & 0.486
\end{tabular}

The table reports the impact of the reform on tertiary education outcomes by SES quartile. We present the RD-DD estimates where we augment the regression with students born in October-March in the neighboring non-reform years 1982-1983, 1984-1985, 1985-1986, 1986-1987, and 1987-1988. The discontinuity in outcomes is estimated with a local linear regression with separate trends on each side of the cutoff, using a 3-month bandwidth on each side of the cutoff and a triangular kernel. 


\section{References in Swedish}

In this section we present the detailed references in Swedish for readers interested in the regulations governing the school system in Sweden.

\section{References}

Ds 2008:13 (2008). En ny betygsskala. Stockholm: Utbildningsdepartementet.

Grevholm B.(1999). Varför och hur revideras kursplanerna för gymnasieskolan? Nämnaren $26(1), 41-44$

GY2000:14 (2000). Naturvetenskapsprogrammet: programmål, kursplaner, betygskriterier och kommentarer. Stockholm: Skolverket.

GY2000:16 (2000). Samhällsvetenskapsprogrammet:programmål, kursplaner, betygskriterier och kommentarer. Stockholm: Skolverket.

GY2000:17 (2000). Teknikprogrammet: programmål, kursplaner, betygskriterier och kommentarer. Stockholm: Skolverket

GyVux 1994/95:14 (1995). Naturvetenskapsprogrammet: Programmål, kursplaner, betygskriterier och kommentarer. Stockholm: Skolverket

GyVux 1994/97:16 (1997). Samhällsvetenskapsprogrammet:Programmål, kursplaner, betygskriterier och kommentarer. Stockholm: Skolverket

GyVux 1994/97:17 (1997). Programhandledning: Programöversikter samt förteckning över ämnen och kurser. Stockholm: Skolverket

Högskoleverket (2010). Swedish universities \& university colleges Short version of annual report 2010. http : //english.uka.se/download/18.6b3261a315a296ca0f3e77bd/1487932600878/annualreport-2010.pdf (accessed Aug 31, 2018)

Proposition 1997/98:169 (1998).Gymnasieskola i utveckling - kvalitet och likvärdighet. Stockholm: Utbildningsdepartementet. 
SACO (2018).Fastighetsmäklare. https ://www.saco.se/studieval/yrken-a-o/fastighetsmaklare/ (accessed Aug 30, 2018)

SCB (2011). Utbildningssystemet. https ://www.scb.se/sv/Hitta-statistik/Publiceringskalender/Visadetaljerad - information/?publobjid = 1739 (accessed Aug 31, 2018)

Skolverket (1998). Redovisning av regeringens uppdrag 1998- 03-12 angående gymnasieskolans utveckling - U98/1135/S(Dnr. 98:956)

Skolverket (2000).Beskrivande data om barnomsorg och skola 2000 (Dnr:2000:2208)

Skolverket (2001). Beskrivande data om barnomsorg,skola och vuxenutbildning 2001. (Dnr: 71-2001:3248)

Skolverket (2005). Var fjärde 20-åring saknar slutbetyg från gymnasiet. https : //web.archive.org/web/200710 //www.skolverket.se/sb/d/204\%3Bjsessionid\%3DF DCB3425AAA8BF F25B3450F92DC5C112 (accessed Aug 30, 2018)

Universitets- och högskolerådet (UHR) (2016). Tabell för områdesbehörigheter. Available at: https ://www.uhr.se/globalassets/uhr.se/studier - och - antagning/tilltrade - till hogskolan/tabell - for - omomradesbehorigheter - 2016.pdf (accessed Jan 31, 2018) 